\title{
Recovery of organic-enriched sediments through microbial degradation: implications for eutrophic estuaries
}

\author{
Thomas Valdemarsen $^{1, *}$, Cintia O. Quintana ${ }^{1,2}$, Erik Kristensen ${ }^{1}$, Mogens R. Flindt ${ }^{1}$ \\ ${ }^{1}$ Institute of Biology, University of Southern Denmark, 5230 Odense M, Denmark \\ ${ }^{2}$ Institute of Oceanography, University of São Paulo, São Paulo 05508-070, Brazil
}

\begin{abstract}
Sediments in eutrophic estuarine ecosystems may become heavily enriched with organic carbon (OC). This OC is primarily of low reactivity and, therefore, has moderate effects on sediment biogeochemical cycling. Nonetheless, OC levels of $>1 \%$ reduce sediment stability and cause frequent resuspensions and high water turbidity, which affect the recovery of ecosystem functioning. Significant reduction of sediment OC content to $<1 \%$ is, therefore, needed before ecosystems can fully recover. It was investigated whether organic-rich sediments with 2.5 to $4.4 \%$ OC (180-310 mol m${ }^{-2}$ ) from the eutrophic Odense Fjord (Denmark) can recover by microbial degradation. Defaunated sediment cores from various habitats were subjected to long-term ( 2 yr) degradation experiments. Total OC content was measured initially and OC degradation was measured regularly from $\mathrm{CO}_{2}$ effluxes and closed anoxic sediment incubations. OC degradation was high initially, but faded exponentially at all stations before stabilizing at 6 to $15 \mathrm{mmol} \mathrm{OC} \mathrm{m}{ }^{-2}$ $\mathrm{d}^{-1}$ after 100 to $150 \mathrm{~d}$. Hence, over the 2 yr experiment OC degradation corresponded to only 3 to $5 \%$ reduction of initial OC. Temporal degradation patterns analyzed by exponential decay models suggested that sedimentary OC consisted of 2 pools with different reactivity plus a non-reactive pool. OC with the highest turnover $\left(k=0.5 \times 10^{-2}\right.$ to $\left.5.5 \times 10^{-2} \mathrm{~d}^{-1}\right)$ was quantitatively the least important $\left(0.3-4.3 \%\right.$ of total OC), while OC with lower reactivity $\left(k=0.1 \times 10^{-3}\right.$ to $\left.2.0 \times 10^{-3} \mathrm{~d}^{-1}\right)$ constituted a higher proportion (4-58\% of total OC in organic-rich sediments). Furthermore, 43 to $95 \%$ of sediment OC was non-degradable. Our results suggest that partial recovery $(5-57 \%$ reduction of initial OC) may occur within 23 to 50 yr. However, complete recovery of organic-rich sediments to $<1 \%$ OC seems unlikely due to large pools of non-reactive OC. Eutrophication, therefore, leads to irreversible $\mathrm{OC}$ accumulation in sediments, which prolongs the recovery time for estuarine ecosystems after reductions in nutrient loading.
\end{abstract}

KEY WORDS: Organic matter · Degradation · Mineralization · Oligotrophication · Recovery time · Exponential decay · G-model

Resale or republication not permitted without written consent of the publisher

\section{INTRODUCTION}

Elevated anthropogenic nutrient loading and associated increased primary productivity in coastal marine ecosystems ('eutrophication' sensu Nixon 1995) may cause substantial organic enrichment of estuarine sediments. Most of the organic carbon (OC) associated with excess organic matter consists of micro- and macroalgal debris, which is labile and readily degradable within weeks by heterotrophic microbes in the water and sediments (Harvey et al. 1995, Wetz et al. 2008). Increased input of labile OC to sediments may, therefore, cause an instant biogeochemical response in the form of higher rates of microbial sulfate reduction, toxic sulfide accumulation, reduced conditions and increased $\mathrm{O}_{2}$ consumption at the sediment- 
water interface (Valdemarsen et al. 2009, 2010a). Prolonged enrichment with labile $\mathrm{OC}$ is, thus, a major driver for widespread hypoxia and detrimental effects on benthic fauna and vegetation in eutrophic ecosystems (e.g. Gray et al. 2002, Orth et al. 2006, Kemp et al. 2009, Mascaro et al. 2009).

Nevertheless, bulk OC consists of multiple fractions with widely different reactivities towards microbial degradation (Westrich \& Berner 1984). The most labile OC fractions degrade equally fast irrespective of redox conditions and microbial pathways, while the more refractory fractions degrade faster under oxic than anoxic conditions (e.g. Aller 1994, Kristensen et al. 1995, Hulthe et al. 1998, Kristensen \& Holmer 2001). Degradation of redox-sensitive OC may thus be impeded by the anoxic conditions prevailing below just a few $\mathrm{mm}$ of depth in estuarine sediments (Glud 2008). The most labile fractions of recently deposited OC are typically associated with proteins and simple carbohydrates, whereas structural components containing lipids and cellulose are examples of refractory compounds (Harvey et al. 1995, Sun et al. 2002, Valdemarsen \& Kristensen 2010). A fraction of recently deposited OC (2-80\%) is so refractory that it is persistent over time scales of months to years (Burdige 1991, Roden \& Tuttle 1996). Complete degradation of OC in sediments can therefore be a lengthy process, despite a fast decay of the labile fraction. Eutrophication of coastal ecosystems thus leads to accumulation of low reactivity $\mathrm{OC}$ within the sediments. The long-term effects of eutrophication on sediment organic content is not well known, but recent investigations in estuaries suggest dramatically elevated levels (e.g. 2-3 times the background level) following decades of eutrophication (Zimmerman \& Canuel 2002, Vaalgamaa 2004).

The accumulation of OC with low reactivity may have wide implications for ecosystem recovery after oligotrophication (i.e. reduced organic matter loading sensu Nixon 2009). Elevated OC is followed by fundamental changes in sediment properties and texture (e.g. higher water content and porosity). These changes lower the sediment stability leading to erosion (Amos et al. 2004, Lundkvist 2008) and ecosystems with organic-enriched sediments, therefore, have higher resuspension frequency and water column turbidity (Lundkvist et al. 2007, Canal-Verges et al. 2010). Low water clarity can persist in ecosystems with organic-rich sediments, even after significant reduction of the external nutrient loading, which prevents the recovery of light dependent organisms such as benthic diatoms, seagrasses and macroalgae. In addition, organic-rich sediment is a poor sub- stratum for rooted marine macrophytes, due to low anchoring capacity (Wicks et al. 2009, Lillebø et al. 2012). Studies suggest that sediment stability is severely reduced at $\mathrm{OC}$ levels as low as $1 \%$ (M. Flindt et al. unpubl. data).

The ecological implications of OC accumulation in sediments raise one relevant question: How long will it take for sediments to recover after oligotrophication? Ecosystem recovery with respect to, for example, water transparency and vegetation coverage will be prolonged if the accumulated organic matter persists for extended time and may hence explain some of the time lag (decades to centuries) estimated for improvements in ecological functioning after oligotrophication (Jones \& Schmitz 2009, Borja et al. 2010). Various explanations, e.g. shifting baselines and regime shifts, have been proposed to explain this apparent lack of recovery (e.g. Duarte et al. 2009). However, there may be a much simpler explanation for the lack of ecosystem recovery. The eutrophication-driven impacts may have simply accumulated and persisted in the sediments, counteracting legislative measures to improve ecological quality. OC accumulated in sediments may persist for an extended time, and reliable estimates of sediment recovery are urgently needed to precisely evaluate ecosystem response to oligotrophication.

The present study examines the temporal recovery pattern driven by microbial processes in sediments from Odense Fjord, Denmark. This shallow estuary was heavily eutrophied from ca. 1960 to 2000 due to excessive nutrient discharges from anthropogenic sources (Petersen et al. 2009). After implementation of several water action plans, the nutrient loading is now significantly reduced (about 30 and $80 \%$ for $\mathrm{N}$ and $\mathrm{P}$, respectively), but with only minor improvements in ecological quality, following nationwide trends for Danish estuaries and coastal waters (Kronvang et al. 2005). The lack of recovery may be linked to the sediments, which are heavily enriched with OC. A fjord-wide survey in 2008 and 2009 covering $>90$ sites showed that $46 \%$ of the bottom in Odense Fjord, including previous seagrass habitats, now consists of bare sediments with 2 to $10 \%$ OC content (see Fig. 1).

The aim of this study was to investigate if sediments enriched with $\mathrm{OC}$ and nutrients after decades of eutrophication are able to recover by microbial degradation, and if so, how long it would take. OC degradation was followed for an extended period $(\sim 2 \mathrm{yr})$ in sediments with variable organic content collected from 8 locations in Odense Fjord. We present here the results on carbon (C) dynamics, whereas 
the corresponding fate of sediment bound nutrients will be presented in a companion paper ( $\mathrm{T}$. Valdemarsen unpubl. data). Initial OC pools were identified by solid phase measurements, and the temporal pattern of OC degradation was measured as the sum of $\mathrm{CO}_{2}$ and dissolved organic $\mathrm{C}$ (DOC) formation. The results were fitted to exponential decay models, which provided important information regarding the longterm fate of organic matter in the sediments.

\section{MATERIALS AND METHODS}

\section{Sampling site}

Odense Fjord is a $62 \mathrm{~km}^{2}$ shallow Danish estuary, with an average water depth of $2.2 \mathrm{~m}\left(55^{\circ} 29^{\prime} 15^{\prime \prime} \mathrm{N}\right.$, $10^{\circ} 31^{\prime} 09^{\prime \prime} \mathrm{E}_{\text {; Fig. }}$ ). The inner fjord consists of a $16 \mathrm{~km}^{2}$ basin (average depth $0.8 \mathrm{~m}$ ), which is impacted by freshwater and nutrient runoff from the Odense River outlet at the head towards the southwest. The $46 \mathrm{~km}^{2}$ outer basin has a more variable bathymetry (average depth $2.7 \mathrm{~m}$ ) and opens to the Kattegat through a narrow opening in the northeast. The $1095 \mathrm{~km}^{2}$ catchment area consists mainly of farmland (68\%) and urban areas (16\%) and Odense Fjord was heavily impacted and eutrophic in the past (Petersen et al. 2009). Nutrient loading to the fjord exceeded $3000 \mathrm{t} \mathrm{N} \mathrm{yr}^{-1}$ and $300 \mathrm{t} \mathrm{P} \mathrm{yr}^{-1}$ in the decades preceding the 1990s, causing high concentrations of phytoplankton, low water transparency, mass occurrences of ephemeral macroalgae, hypoxia and reduced seagrass coverage (Greve et al. 2005, Fyns Amt 2006, Petersen et al. 2009). Nutrient loading has been reduced considerably to the current levels of

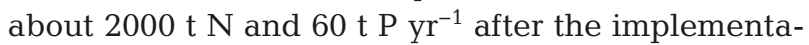
tion of several water action plans. This reduction has improved water quality marginally (e.g. slightly improved water transparency and reduced frequency of algal blooms and hypoxic events), but recovery of seagrasses has still not occurred (Fyns Amt 2006, Valdemarsen et al. 2010b).

\section{Sampling of sediment and water}

Intact sediment cores were collected from 8 locations in Odense Fjord during October and November 2009. Sediment was sampled in autumn, when temperate estuarine sediments typically have the highest concentrations of organic matter. The stations were chosen to cover all major environments and sediment types in the fjord: 3 stations were located in the shallow inner basin and 5 stations in the outer basin of Odense Fjord (Fig. 1). Stns 1-5 represent shallow environments $(<1 \mathrm{~m})$ at either sheltered (Stns 1-3) or
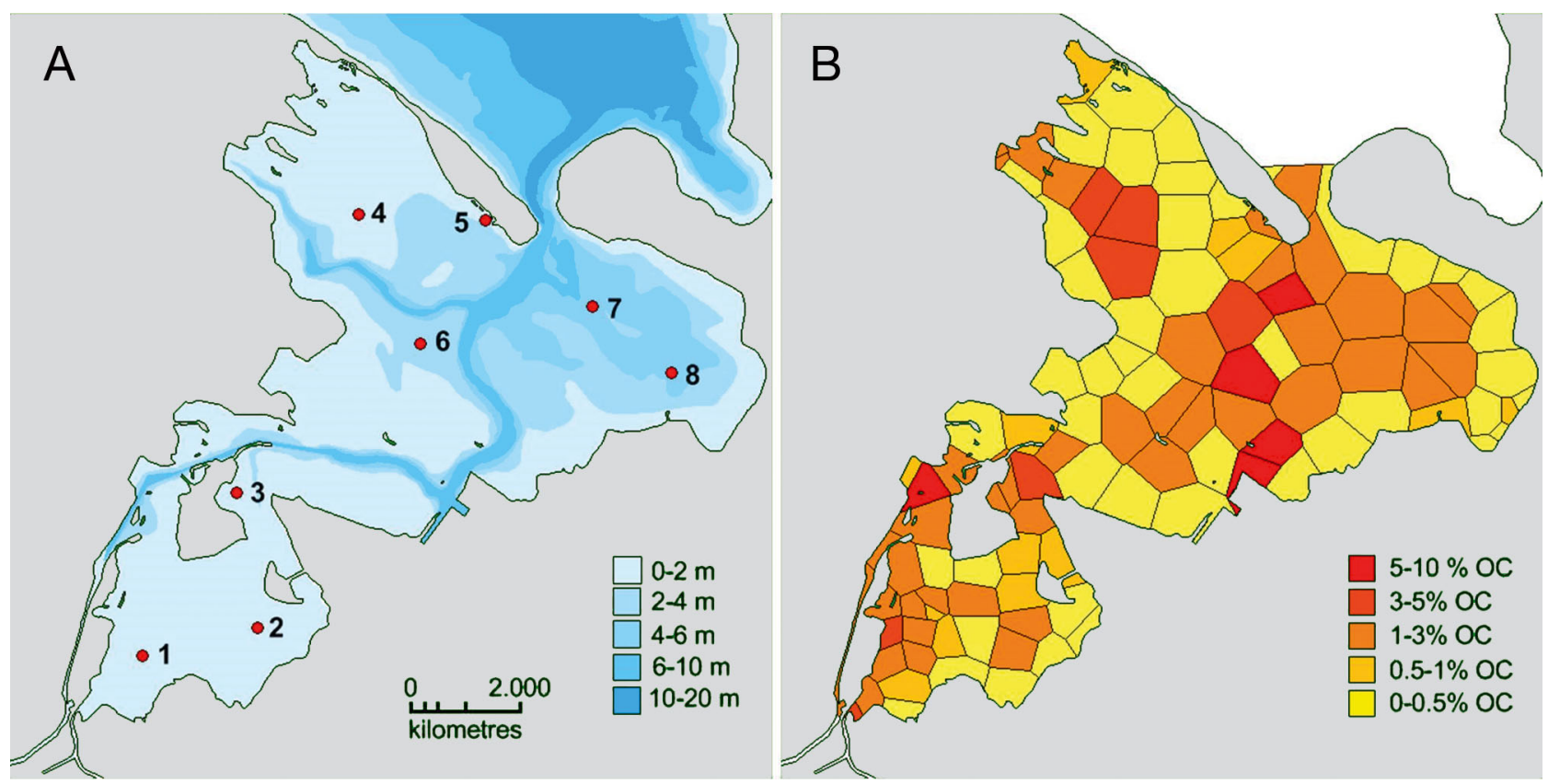

Fig. 1. (A) Location of sampling stations in Odense Fjord. Stns 1-3 were located on shallow water $(<1 \mathrm{~m})$ in the inner fjord. Stns 4-5 and 6-8 were located in shallow $(<1 \mathrm{~m})$ and deep $(2-6 \mathrm{~m})$ water in the outer fjord, respectively. (B) Average organic $\mathrm{C}(\mathrm{OC})$ content $(0-15 \mathrm{~cm})$ of the sediment in Odense fjord based on a survey conducted in 2009 (M. Flindt et al. unpubl.) 
more exposed locations (Stns 4 \& 5). Stns 6-8 represent the deeper parts $(2-6 \mathrm{~m})$ of the outer fjord, which are sedimentation areas for fine particulate matter; 15 cores were sampled from each station with $30 \mathrm{~cm}$ long, $8 \mathrm{~cm}$ internal diameter Plexiglas core liners. The shallow stations were sampled from a dinghy using a hand operated coring device. The deeper stations were sampled with a 'HAPS' box corer on board a larger vessel ('Liv II', Danish Nature Agency). Water temperatures were 10 to $12^{\circ} \mathrm{C}$ at the time of sampling.

Filtered seawater with a salinity of 26 to 30 was collected at Kerteminde Harbor at various times during 2009 to 2011. The seawater was adjusted to the appropriate salinity (10 or 20 ) with distilled water. To ensure similar experimental conditions, the water was enriched to $28 \mathrm{mM} \mathrm{SO}_{4}{ }^{2-}$ before it was used for experiments.

\section{Handling of sediment cores}

Sediment cores were pre-treated before the experiment to assure that they had equal sediment heights, were free of macrofauna and had sufficient levels of porewater $\mathrm{SO}_{4}{ }^{2-}$ to maintain sulfate reducing conditions. The cores were adjusted to $20 \mathrm{~cm}$ depth by removing the bottom stopper and carefully removing excess sediment from below. After reinserting the bottom stopper, the top stopper was removed and the overlying water was purged with $\mathrm{N}_{2}$ for $30 \mathrm{~min}$ to induce anoxic conditions. The top stopper was reinserted and sediment cores were left for $\sim 48 \mathrm{~h}$ in darkness, after which asphyxiated macrofauna were removed from the sediment surface. This is a common procedure to defaunate sediment cores with an efficiency of 90 to $100 \%$ (Valdemarsen et al. 2010a). The sediment was enriched with $\mathrm{SO}_{4}{ }^{2-}$ by injecting $0.4 \mathrm{ml}$ of $1 \mathrm{M} \mathrm{NaSO}_{4}$ through a $25 \mathrm{~cm}$ long, $2 \mathrm{~mm}$ diameter hypodermic needle at $1 \mathrm{~cm}$ intervals into the center of each sediment core. The enrichment corresponded to $+16 \mathrm{mM} \mathrm{SO}_{4}{ }^{2-}$ in sediments with a porosity of 0.5 .

\section{Experimental setup}

When the pre-treatment was completed 2 to $4 \mathrm{~d}$ after sampling, sediment cores were transferred to the experimental setup consisting of eight $\sim 70 \mathrm{l}$ water tanks located in a temperature controlled room at $15^{\circ} \mathrm{C}$. Each tank contained all sediment cores from one station, and was filled with filtered seawater with salinity 10 for Stns $1-3$ and salinity 20 for Stns $4-8$, corresponding to the average salinity in the inner and outer basins of Odense Fjord (Fyns Amt 2006). The water reservoir in each tank was vigorously mixed and aerated by air pumps, and kept at a level $0.5 \mathrm{~cm}$ above the upper rim of the open core liners to assure mixing of the headspace. The tanks were kept in darkness and about 1/3 of the water was renewed with fresh seawater every $2 \mathrm{wk}$ to avoid accumulation or depletion of metabolites in the ambient water.

The sediment cores were maintained in this setup for the entire experiment, which lasted 589 to $635 \mathrm{~d}$, depending on the station. The time when cores were first transferred to the incubation tanks is referred to as $t=0$. At selected times, 3 random sediment cores were temporarily removed from the incubation tanks for flux measurements (see below), and at other times 3 sediment cores were removed permanently for porewater and solid phase analysis as well as anoxic incubations (see below).

\section{Flux measurements}

Total benthic metabolism was determined as the flux of total carbon dioxide $\left(\mathrm{TCO}_{2}\right)\left(=\mathrm{CO}_{3}{ }^{2-}+\right.$ $\mathrm{HCO}_{3}{ }^{-}+\mathrm{H}_{2} \mathrm{CO}_{3}$ ) between sediment and water. Flux measurements were conducted with 3 random sediment cores from each station at selected time intervals (weekly during the first $30 \mathrm{~d}$, monthly until Day 180 and every 2 to 3 mo to the end). Since bacterial biofilms on the inner surface of core liners may result in significantly overestimated fluxes (Valdemarsen \& Kristensen 2005), the inside headspace wall of the cores designated for flux measurements were cleaned with a Q-tip $1 \mathrm{~d}$ prior to flux measurements. The cores were removed from the incubation tanks during flux experiments, equipped with $4 \mathrm{~cm}$ long magnetic stirring bars a few $\mathrm{cm}$ above the sediment surface and placed around a central magnet rotating at $60 \mathrm{rpm}$. Initial water samples were taken from all cores, before they were closed with rubber stoppers. At the end of incubations, the rubber stoppers were removed and final water samples were taken. Samples of $3 \mathrm{ml}$ for $\mathrm{TCO}_{2}$ were preserved with saturated $\mathrm{HgCl}_{2}$ (30 $\mathrm{\mu l}$ per ml sample) and analyzed by flow injection analysis (Hall \& Aller 1992). Since microbial activity decreased as the experiment progressed, successively longer incubations were needed to obtain significant concentration changes during core incubations. Flux experiments lasted $4 \mathrm{~h}$ initially and up to $24 \mathrm{~h}$ at the end of the experiment. 


\section{Core sectioning}

We sectioned 3 sediment cores from each station at various times (after $1 \mathrm{~d}$ and after 1, 7-8, 16-17 and 20-21 mo). Core sectioning and subsequent sediment and porewater handling was done inside an $\mathrm{N}_{2}$-filled glovebag. Sediment cores were sliced into $2 \mathrm{~cm}$ intervals to $16 \mathrm{~cm}$ depth. The sediment slices were homogenized and porewater for $\mathrm{TCO}_{2}, \mathrm{DOC}$ and $\mathrm{SO}_{4}{ }^{2-}$ analysis was obtained after centrifugation of sediment subsamples in double centrifuge tubes (10 min, 500 g) and GF/C filtration. $\mathrm{TCO}_{2}$ samples were stored and analyzed as described above. Samples for DOC and $\mathrm{SO}_{4}{ }^{2-}$ were stored frozen $\left(-20^{\circ} \mathrm{C}\right)$ until analysis. DOC samples were acidified and analyzed on a Shimadzu TOC-5000 Total Organic Analyzer and $\mathrm{SO}_{4}{ }^{2-}$ was analyzed by liquid ion chromatography on a Dionex ICS-2000 system.

Sediment characteristics were determined on subsamples from every depth interval during the core sectioning on Day 1. Sediment density was determined gravimetrically using a cut-off syringe. Water content was determined as weight loss of wet sediment after drying $\left(24 \mathrm{~h}, 100^{\circ} \mathrm{C}\right)$ and organic content was determined as weight loss of dry sediment after ignition $\left(5 \mathrm{~h}, 520^{\circ} \mathrm{C}\right.$, loss on ignition [LOI]). Sediment particle composition and median grain size were determined for a pooled subsample from the 0-2, 4-6 and $8-10 \mathrm{~cm}$ depth intervals by wet sieving through a Wentworth mesh series $(1000,500,250,125$ and $63 \mu \mathrm{m})$. The medium grain size was calculated from the $\phi$ distribution of dry-weight size fractions (Bale \& Kenny 2005). Total organic carbon (TOC) was also determined on selected sediment subsamples $(n=64$, 8 samples from each station) by elemental analysis on a Carlo Erba CHN EA1108 Elemental Analyzer according to Kristensen \& Andersen (1987).

\section{Closed anoxic sediment incubations}

After core sectioning, excess sediment from selected depth intervals $(0-2,4-6$ and $8-10 \mathrm{~cm})$ was used for closed anoxic sediment incubations to determine net microbial reaction rates (Kristensen \& Hansen 1995, Valdemarsen et al. 2012). The sediment from each depth interval was homogenized and fully packed into 6 to 8 scintillation vials $(20 \mathrm{ml})$, leaving no headspace. These 'jars' were closed with screw caps and buried in anoxic sediment at $15^{\circ} \mathrm{C}$. Two jars were sacrificed at 3 to 5 d intervals for porewater extraction by centrifugation. Before centrifugation the scintillation vials were fitted with a perforated lid con- taining a GF/C filter inside. The jars were then centrifuged head-down in a centrifuge tube (10 min, $\sim 500 \mathrm{~g}$ ) and extracted porewater was sampled and analyzed for $\mathrm{TCO}_{2}$ and $\mathrm{SO}_{4}{ }^{2-}$ as described above.

\section{Decay modelling}

The temporal development of $\mathrm{C}$ mineralization based on $\mathrm{TCO}_{2}$ effluxes and depth integrated $\mathrm{TCO}_{2}$ production in jar experiments was fitted to a double exponential decay model in the form:

$$
y=C_{L} \mathrm{e}^{-k_{L} \cdot t}+C_{R} \mathrm{e}^{-k_{R} \cdot t}
$$

where $t$ is time, $C_{L}$ and $C_{R}$ are constants describing the contribution of the labile $(L)$ and refractory $(R)$ fraction to the initial total C mineralization $(t=0)$, and $k_{L}$ and $k_{R}$ denote first order decay constants for labile and refractory $\mathrm{OC}$, respectively. With this approach, we assume that organic matter decay at the selected stations can be described adequately as 2 pools with distinct reactivities; labile OC and refractory OC with relatively high and low reactivity regarding microbial degradation, respectively. Several studies show that this procedure is useful when describing the decay dynamics within the time frame studied here (Westrich \& Berner 1984, Lehmann et al. 2002).

The pool-sizes of labile and refractory OC $\left(O C_{L}\right.$ and $O C_{R}$ ) could subsequently be calculated by separate infinite integration of each term in Eq. (1):

$$
\begin{gathered}
O C_{L}=C_{L} \int_{0}^{\infty} \mathrm{e}^{-k_{L} \cdot t} \mathrm{~d} t=\frac{C_{L}}{k_{L}} \\
O C_{R}=C_{R} \int_{0}^{\infty} \mathrm{e}^{-k_{R} \cdot t} \mathrm{~d} t=\frac{C_{R}}{k_{R}}
\end{gathered}
$$

Non-reactive OC $\left(O C_{N R}\right)$ could hereafter be calculated by subtracting the pools of labile and refractory OC from total OC at each station.

Half lives of labile and refractory OC were calculated from the equation:

$$
T_{\frac{1}{2}}=\frac{\ln (2)}{k_{X}}
$$

where $k_{X}$ represents the first order decay constants, $k_{L}$ and $k_{R}$, for labile and refractory OC, respectively.

\section{Calculations and statistical procedures}

Total C mineralization in sediment cores was calculated from the $\mathrm{TCO}_{2}$ concentration change in the core headspace during flux experiments and is pre- 
sented as mmol m $\mathrm{m}^{-2} \mathrm{~d}^{-1}$. Rates of microbial OC oxidation and sulfate reduction in discrete depth intervals $(0-2,4-6$ and $8-10 \mathrm{~cm})$ were obtained from jar experiments by fitting the time dependent linear concentration change of $\mathrm{TCO}_{2}$ and $\mathrm{SO}_{4}{ }^{2-}$ by leastsquares regression (Aller \& Yingst 1980). When the slope was significant $(p<0.05)$, the volume specific reaction rates $\left(\mathrm{nmol} \mathrm{cm} \mathrm{cm}^{-3} \mathrm{~d}^{-1}\right)$ in individual depth layers were calculated from the slopes of regressions after correction for sediment porosity (Kristensen \& Hansen 1995). Estimates of total C mineralization, based on jar experiments, were calculated by depth integration $(0-10 \mathrm{~cm})$ of $\mathrm{TCO}_{2}$-production rates obtained at different depths. The total areaspecific $\mathrm{C}$ mineralization based on flux and jar experiments were fitted to double exponential decay models as described above. Least-squares regression was used to test for significant relationships between LOI and OC content in sediments and between $\mathrm{TCO}_{2}$ production and $\mathrm{SO}_{4}{ }^{2-}$ consumption in jar experiments. Statistical analysis and double exponential regressions were performed with Sigmaplot 11.0.

\section{RESULTS}

\section{Sediment characteristics and organic content}

The sediments had wet densities ranging between 1.3 and $1.8 \mathrm{~g} \mathrm{~cm}^{-3}$ with $18-57 \%$ water content (Table 1). Most of the stations showed variable LOI with depth. LOI varied between 0.8 and $4.7 \%$ in the $0-2,4-6$ and $8-10 \mathrm{~cm}$ depth intervals at most of the stations (Table 1), but was even higher below $10 \mathrm{~cm}$ depth at several stations (up to $8-10 \%$ at Stns 2 and 3 , data not shown). Stn 5 deviated from the general trend since it was poor in organic matter at all depths (LOI $\sim 0.1-0.3 \%$ ). All sediments consisted of fine to medium sand with a median grain size ranging from 87 to $397 \mu \mathrm{m}$ and 4 to $68 \%$ silt-clay content. The majority of the sediments had heterogeneous brown/ black/gray coloration, which is characteristic for organic-rich estuarine sediments. Stn 5 was again an exception, since it was homogeneous in texture and color at all depths (light brown to light grey). Several of the shallow stations (Stns 1-4) had a high content of partially degraded shell material originating from

Table 1. Density, water content, loss on ignition (LOI), median grain size and silt-clay content of sediments sampled from 8 stations in Odense Fjord. Error values indicate standard deviation $(\mathrm{n}=3)$

\begin{tabular}{|c|c|c|c|c|c|c|c|}
\hline & $\begin{array}{l}\text { Depth } \\
(\mathrm{cm})\end{array}$ & $\begin{array}{l}\text { Density } \\
\left(\mathrm{g} \mathrm{cm}^{-3}\right)\end{array}$ & $\begin{array}{c}\text { Water } \\
\text { content } \\
(\%)\end{array}$ & LOI (\%) & $\begin{array}{c}\text { Median } \\
\text { grain size } \\
(\mu \mathrm{m})\end{array}$ & $\begin{array}{c}\text { Silt-clay } \\
\text { content } \\
(\%)\end{array}$ & Note \\
\hline Stn 1 & $\begin{array}{c}0-2 \\
4-6 \\
8-10\end{array}$ & $\begin{array}{l}1.45 \pm 0.02 \\
1.49 \pm 0.07 \\
1.48 \pm 0.04\end{array}$ & $\begin{array}{l}45.2 \pm 1.4 \\
43.3 \pm 4.5 \\
45.3 \pm 3.1\end{array}$ & $\begin{array}{l}2.50 \pm 0.03 \\
3.05 \pm 0.01 \\
2.61 \pm 0.09\end{array}$ & $\begin{array}{l}198 \\
190 \\
397\end{array}$ & $\begin{array}{l}28.8 \\
17.4 \\
13.9\end{array}$ & $\begin{array}{l}\text { Degraded shell material } \\
\text { at all depths }\end{array}$ \\
\hline Stn 2 & $\begin{array}{c}0-2 \\
4-6 \\
8-10\end{array}$ & $\begin{array}{l}1.48 \pm 0.03 \\
1.53 \pm 0.11 \\
1.52 \pm 0.07\end{array}$ & $\begin{array}{l}43.5 \pm 2.0 \\
38.9 \pm 7.1 \\
40.0 \pm 6.1\end{array}$ & $\begin{array}{l}3.37 \pm 0.04 \\
3.58 \pm 0.05 \\
3.49 \pm 0.12\end{array}$ & $\begin{array}{c}113 \\
97 \\
110\end{array}$ & $\begin{array}{l}14.4 \\
23.4 \\
24.9\end{array}$ & $\begin{array}{l}\text { Layer of degraded shell } \\
\text { material from } 8-12 \mathrm{~cm}\end{array}$ \\
\hline Stn 3 & $\begin{array}{c}0-2 \\
4-6 \\
8-10\end{array}$ & $\begin{array}{l}1.64 \pm 0.12 \\
1.81 \pm 0.12 \\
1.42 \pm 0.10\end{array}$ & $\begin{array}{c}30.5 \pm 3.4 \\
22.5 \pm 5.3 \\
41.8 \pm 12.9\end{array}$ & $\begin{array}{l}1.73 \pm 0.07 \\
1.11 \pm 0.09 \\
3.14 \pm 0.15\end{array}$ & $\begin{array}{l}180 \\
390 \\
394\end{array}$ & $\begin{array}{l}14.8 \\
6.4 \\
6.8\end{array}$ & $\begin{array}{l}\text { Layer of degraded shell } \\
\text { material from } 6-8 \mathrm{~cm}\end{array}$ \\
\hline Stn 4 & $\begin{array}{c}0-2 \\
4-6 \\
8-10\end{array}$ & $\begin{array}{l}1.73 \pm 0.10 \\
1.55 \pm 0.18 \\
1.45 \pm 0.07\end{array}$ & $\begin{array}{c}29.0 \pm 5.5 \\
39.2 \pm 12.3 \\
45.1 \pm 5.5\end{array}$ & $\begin{array}{l}0.82 \pm 0.08 \\
2.59 \pm 0.45 \\
3.94 \pm 0.34\end{array}$ & $\begin{array}{l}187 \\
181 \\
155\end{array}$ & $\begin{array}{l}15.0 \\
26.3 \\
39.9\end{array}$ & $\begin{array}{l}\text { Layer of degraded shell } \\
\text { material from } 14-16 \mathrm{~cm}\end{array}$ \\
\hline Stn 5 & $\begin{array}{c}0-2 \\
4-6 \\
8-10\end{array}$ & $\begin{array}{l}1.82 \pm 0.03 \\
1.80 \pm 0.05 \\
1.79 \pm 0.05\end{array}$ & $\begin{array}{l}20.8 \pm 0.7 \\
19.0 \pm 0.7 \\
18.7 \pm 0.1\end{array}$ & $\begin{array}{l}0.29 \pm 0.04 \\
0.19 \pm 0.06 \\
0.16 \pm 0.01\end{array}$ & $\begin{array}{l}173 \\
166 \\
173\end{array}$ & $\begin{array}{l}4.0 \\
7.2 \\
3.8\end{array}$ & $\begin{array}{l}\text { Well sorted medium sand. } \\
\text { No shell material }\end{array}$ \\
\hline Stn 6 & $\begin{array}{c}0-2 \\
4-6 \\
8-10\end{array}$ & $\begin{array}{l}1.33 \pm 0.04 \\
1.52 \pm 0.09 \\
1.49 \pm 0.10\end{array}$ & $\begin{array}{l}49.4 \pm 1.5 \\
36.3 \pm 6.8 \\
28.2 \pm 3.3\end{array}$ & $\begin{array}{l}3.96 \pm 0.05 \\
2.62 \pm 0.04 \\
2.04 \pm 0.03\end{array}$ & $\begin{array}{c}96 \\
129 \\
147\end{array}$ & $\begin{array}{l}62.7 \\
19.8 \\
23.1\end{array}$ & $\begin{array}{l}\text { No shell material. Muddy } \\
\text { sediment texture }\end{array}$ \\
\hline Stn 7 & $\begin{array}{c}0-2 \\
4-6 \\
8-10\end{array}$ & $\begin{array}{l}1.33 \pm 0.02 \\
1.52 \pm 0.03 \\
1.49 \pm 0.06\end{array}$ & $\begin{array}{l}57.2 \pm 2.2 \\
41.2 \pm 1.7 \\
43.5 \pm 4.6\end{array}$ & $\begin{array}{l}4.66 \pm 0.03 \\
2.93 \pm 0.12 \\
3.83 \pm 0.05\end{array}$ & $\begin{array}{c}87 \\
98 \\
104\end{array}$ & $\begin{array}{l}22.5 \\
14.2 \\
18.3\end{array}$ & $\begin{array}{l}\text { No shell material. Muddy } \\
\text { sediment texture }\end{array}$ \\
\hline Stn 8 & $\begin{array}{c}0-2 \\
4-6 \\
8-10\end{array}$ & $\begin{array}{l}1.51 \pm 0.02 \\
1.64 \pm 0.03 \\
1.61 \pm 0.02\end{array}$ & $\begin{array}{l}43.2 \pm 1.9 \\
34.1 \pm 0.9 \\
35.5 \pm 1.5\end{array}$ & $\begin{array}{l}3.10 \pm 0.05 \\
2.46 \pm 0.04 \\
3.15 \pm 0.08\end{array}$ & $\begin{array}{c}96 \\
105 \\
113\end{array}$ & $\begin{array}{l}22.5 \\
16.0 \\
12.7\end{array}$ & $\begin{array}{l}\text { No shell material. Muddy } \\
\text { sediment texture }\end{array}$ \\
\hline
\end{tabular}


gastropods and bivalves (Table 1). The sediments from the deep stations in the outer fjord were devoid of shell material and had a muddy texture.

There was a significant linear relationship between TOC and LOI for 64 selected sediment subsamples analyzed for both parameters $(\mathrm{TOC}=0.4993 \times \mathrm{LOI}$, $\mathrm{R}^{2}=0.844, \mathrm{p}<10^{-3}$ ). Hence, initial TOC was estimated from LOI for all stations and sediment depths (Fig. 2). TOC content in sediment from the inner fjord (Stns 1-3) was intermediate and constant in the upper $12 \mathrm{~cm}(0.6-3.2 \%)$. TOC remained relatively stable in deeper sediments at Stn 1, whereas an increase of up to $5.2 \%$ was evident below $12 \mathrm{~cm}$ depth at Stns $2 \& 3$. The sediments from the outer fjord were more diverse with respect to TOC content and distribution. The lowest TOC was measured at Stn 5 $(0.1-0.2 \%)$, probably reflecting the wind exposed conditions at this site (Valdemarsen et al. 2010a). TOC either increased or decreased with sediment depth at Stns $4 \& 6$ (from 0.4 to 3.3 and 2.1 to $0.9 \%$ at Stns $4 \&$ 6 , respectively). The deepest stations, Stns $7 \& 8$, showed gradually increasing TOC from $1.3-1.6 \%$ at the surface to $2.5-3.6 \%$ at $15 \mathrm{~cm}$ of depth.

\section{Total benthic metabolism}

Total OC degradation measured as $\mathrm{TCO}_{2}$ efflux varied greatly at the beginning of the experiment (Fig. 3). $\mathrm{TCO}_{2}$ effluxes were initially higher in sediments from the inner fjord (Stns 1-3; 69-130 mmol $\mathrm{m}^{-2} \mathrm{~d}^{-1}$ ) than those from the outer fjord (Stns $4-8$; 24-45 $\mathrm{mmol} \mathrm{m}^{-2} \mathrm{~d}^{-1}$ ). $\mathrm{TCO}_{2}$ effluxes decreased over time at all stations in an exponential pattern that

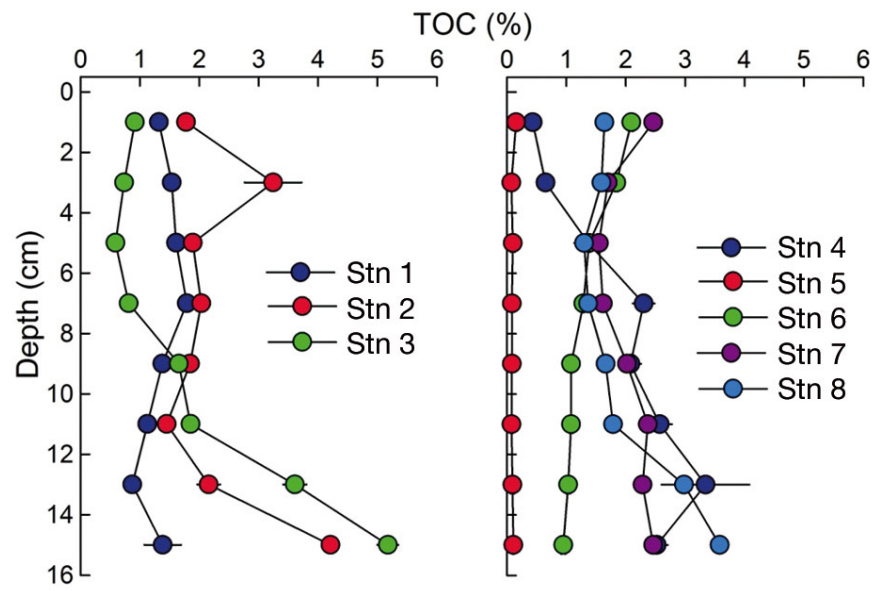

Fig. 2. Content of total organic carbon (TOC) in sediments from inner (Stns 1-3, left panel) and outer (Stns 4-8, right panel) Odense Fjord. TOC was estimated based on loss on ignition (LOI) measured at all stations and sediment depths, and the linear relationship between LOI and TOC content based on selected subsamples $(n=64)$. Error bars: SE $(n=3)$

reflects a gradual depletion of labile OC. The relatively large errors observed initially probably resulted from inter-core variability in the availability of labile OC. Attenuation of total metabolism varied temporally among stations. Thus, $\mathrm{TCO}_{2}$ effluxes were reduced by $52-86 \%$ at Stns $1-5$ after $60 \mathrm{~d}$ but only by $0-31 \%$ at Stns $6-8$, and continued to decline after $200 \mathrm{~d}$ by a total of $71-89 \%$ at Stns $1-5$ and $30-39 \%$ at Stns 6-8. The decrease varied between 41 and $95 \%$ at the end ( 600 d) among all stations, with the most rapid decline at stations with highest initial rates, as indicated by the narrow range of final rates among stations $\left(5.9-15.4 \mathrm{mmol} \mathrm{m}^{-2} \mathrm{~d}^{-1}\right)$.
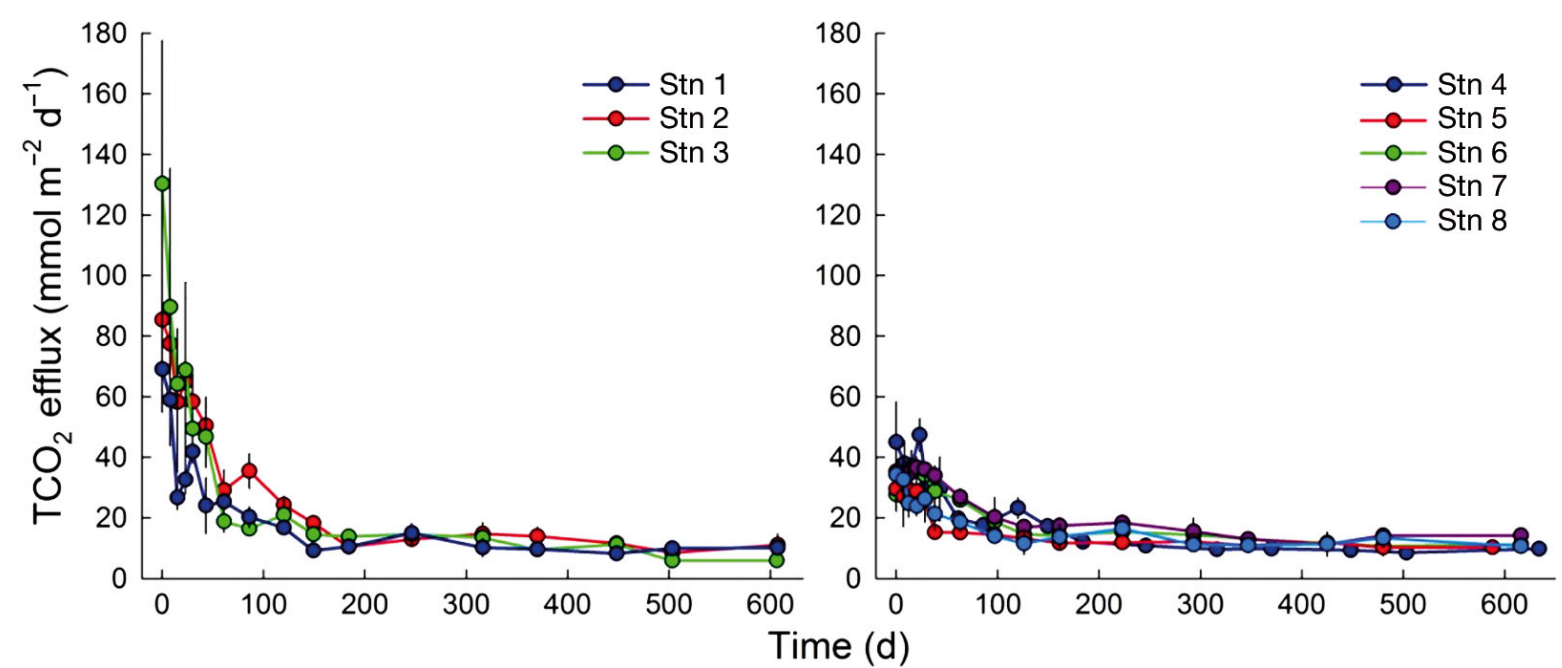

Fig. 3. Total carbon dioxide $\left(\mathrm{TCO}_{2}\right)$ effluxes over time in sediment cores from the inner (Stns 1-3, left panel) and outer (Stns 4-8, right panel) basins in Odense Fjord. Error bars: SE $(n=3)$ 

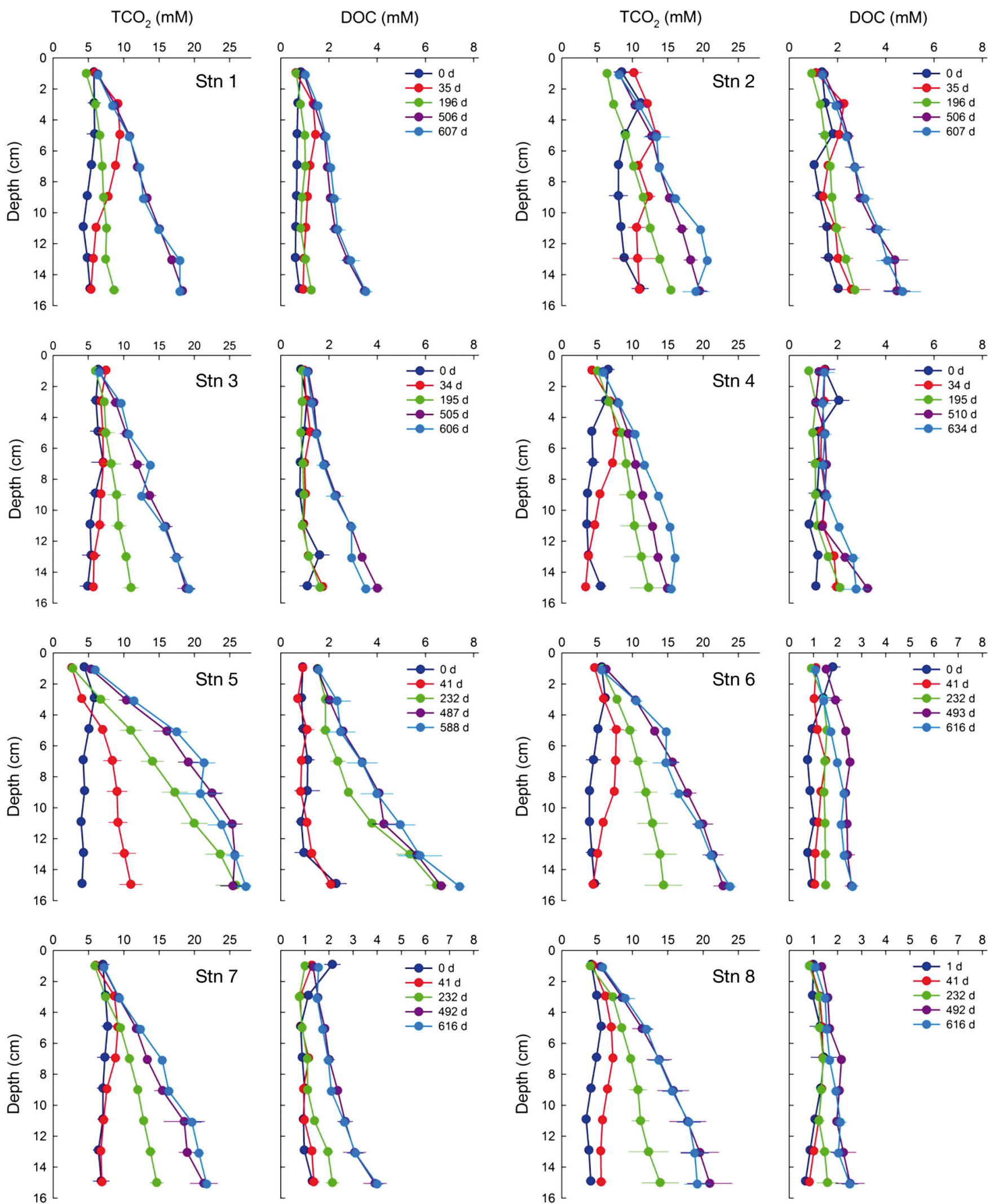

Fig. 4. Porewater profiles of total carbon dioxide $\left(\mathrm{TCO}_{2}\right)$ and dissolved organic carbon (DOC) in defaunated sediment cores from Odense Fjord. The different curves in each panel show the porewater profiles at different times. Error bars: $\mathrm{SE}(\mathrm{n}=3$ ) 


\section{Porewater solutes}

$\mathrm{TCO}_{2}$ in sediment porewater was low and relatively constant with depth at the beginning of the experiment (Fig. 4) and, except for Stn 2, varied between 3.5 and $7.7 \mathrm{mM}$ at all stations and sediment depths. Stn 2 had higher initial $\mathrm{TCO}_{2}$ than the other stations (8.0-11.2 mM). $\mathrm{TCO}_{2}$ accumulated in sediment porewater as the experiment progressed. After $30 \mathrm{~d}$, a surface peak of $\mathrm{TCO}_{2}$ was observed, especially at the stations with the highest initial benthic metabolism (e.g. up to 7.5-13.4 mM at Stns 1-4 where $\mathrm{TCO}_{2}$ efflux was $>69 \mathrm{mmol} \mathrm{m}^{-2} \mathrm{~d}^{-1}$ ). This peak disappeared again after $\sim 200 \mathrm{~d}$, probably due to lower production and diffusive loss of $\mathrm{TCO}_{2}$ to the overlying water. Otherwise, $\mathrm{TCO}_{2}$ accumulated gradually in the sediment porewater throughout the experiment, especially in the deepest sediment layers, where upward transport of $\mathrm{TCO}_{2}$ was limited by diffusion distance. Thus, by the end, $\mathrm{TCO}_{2}$ had accumulated to $15.5-27.3 \mathrm{mM}$ at $15 \mathrm{~cm}$ depth, depending on the station (Fig. 4).

DOC in porewater was also relatively constant with depth at the beginning of the experiment, and varied from 0.4 to $3.1 \mathrm{mM}$ among stations and sediment depths (Fig. 4). DOC accumulated over time below 2 to $4 \mathrm{~cm}$ of depth in all the sampled sediments and, thus, showed a similar pattern as observed for $\mathrm{TCO}_{2}$. By the end of the experiment, DOC had accumulated to $2.5-7.4 \mathrm{mM}$ at $15 \mathrm{~cm}$ depth, depending on the station (Fig. 4).

$\mathrm{SO}_{4}{ }^{2-}$ concentrations were relatively high at the beginning of the experiment due to the initial enrichment and varied between 16 and $39 \mathrm{mM}$ in sediment porewater from all stations and depths (data not shown). No $\mathrm{SO}_{4}{ }^{2-}$ depletion was evident at any station and sediment depth by the end of the experiment as concentrations remained between 14 and $31 \mathrm{mM} . \mathrm{SO}_{4}{ }^{2-}$ thus remained much higher than the rate limiting concentration for sulfate reducing bacteria ( 1-2 mM; Pallud \& Van Cappellen 2006) throughout the experiment.

\section{Microbial reaction rates}

Jar-based $\mathrm{TCO}_{2}$ production in surface sediments (0-2 cm of depth) were higher in the inner (Stns 1-3: 719-3411 $\mathrm{nmol} \mathrm{cm} \mathrm{cm}^{-3} \mathrm{~d}^{-1}$ ) than the outer fjord (Stns $4-8 ; 334-561 \mathrm{nmol} \mathrm{cm}^{-3} \mathrm{~d}^{-1}$; Fig. 5). $\mathrm{TCO}_{2}$ production decreased rapidly in an exponential pattern over time in the surface sediments from Stns 1-3, and was reduced to 4 to $11 \%$ of initial values by the end. $\mathrm{TCO}_{2}$ production also decreased over time in surface sediments from the outer fjord, but only by 11 to $55 \%$ over the whole experiment. Thus, $\mathrm{TCO}_{2}$ production by the end was lower in surface sediments from the inner fjord (41-148 $\mathrm{nmol} \mathrm{cm}{ }^{-3} \mathrm{~d}^{-1}$ ) than those from the outer fjord (168-314 $\mathrm{nmol} \mathrm{cm} \mathrm{cm}^{-3} \mathrm{~d}^{-1}$ ).

$\mathrm{TCO}_{2}$ production in the $4-6 \mathrm{~cm}$ depth interval also decreased markedly over time in sediment from Stns 1-4 and 8, from initial rates of $242-592 \mathrm{nmol} \mathrm{cm}^{-3}$ $\mathrm{d}^{-1}$ to final rates of $18-89 \mathrm{nmol} \mathrm{cm}^{-3} \mathrm{~d}^{-1}$, corresponding to a 78 to $96 \%$ reduction (Fig. 5). Stns 5-7 only showed modest declines in $\mathrm{TCO}_{2}$ production over time in the 4 to $6 \mathrm{~cm}$ depth interval, and initial rates (75-124 $\mathrm{nmol} \mathrm{cm} \mathrm{cm}^{-3} \mathrm{~d}^{-1}$ ) were similar to final rates (83-101 $\mathrm{nmol} \mathrm{cm}^{-3} \mathrm{~d}^{-1}$ ). Initial $\mathrm{TCO}_{2}$ production rates in the $8-10 \mathrm{~cm}$ depth interval ranged from 86 to $366 \mathrm{nmol} \mathrm{cm}{ }^{-3} \mathrm{~d}^{-1}$, depending on the station (Fig. 5). $\mathrm{TCO}_{2}$-production rates also decreased over time in this depth interval, albeit generally less pronounced than observed in the shallower and more reactive sediment. $\mathrm{TCO}_{2}$ production by the end was 14 to $105 \mathrm{nmol}$ $\mathrm{cm}^{-3} \mathrm{~d}^{-1}$, corresponding to a decrease of 28 to $93 \%$.

Depth integrated $\mathrm{TCO}_{2}$ production $(0-10 \mathrm{~cm})$, based on jar experiments (Fig. 5), showed the same area specific decreasing pattern with time as observed for $\mathrm{TCO}_{2}$ effluxes (Fig. 3). The most dramatic decrease occurred in sediments from the inner fjord, Stns $1-3$, where $\mathrm{TCO}_{2}$ production decreased by 88 to $94 \%$ during the experimental period (Fig. 5). At the remaining stations, depth integrated $\mathrm{TCO}_{2}$ production only decreased by 28 to $73 \%$.

Rates of sulfate reduction were also measured in jar experiments (data not shown). Sulfate consumption was negatively correlated to $\mathrm{TCO}_{2}$ production when all data was considered $(y=-0.47 x-6.28, \mathrm{n}=$ $120, \mathrm{R}^{2}=0.964, \mathrm{p}<10^{-3}$ ). The slope suggests a $\sim 1: 2$ ratio between $\mathrm{SO}_{4}{ }^{2-}$ reduction and $\mathrm{TCO}_{2}$ production, indicating that sulfate reduction was the dominating pathway for $\mathrm{C}$ oxidation in jar experiments.

\section{Carbon mineralization budgets}

Total depth integrated OC content $(0-20 \mathrm{~cm}$ depth) varied among stations from only $22 \mathrm{~mol} \mathrm{~m}^{-2}$ at Snt 5 to $180-313 \mathrm{~mol} \mathrm{~m}^{-2}$ at the remaining stations (Table 2). Total $\mathrm{C}$ mineralization estimated as time integrated $\mathrm{TCO}_{2}$ efflux and accumulation of DOC and $\mathrm{TCO}_{2}$ in porewater showed that only a minor fraction of the initial OC was mineralized during the $\sim 600 \mathrm{~d}$ experiment (Table 2). The highest mineralization loss was observed at Stn 5, where $38 \%$ of initial OC was mineralized. At the remaining stations, total $\mathrm{C}$ mineralization corresponded to only 3 to $5 \%$ of initial OC. 

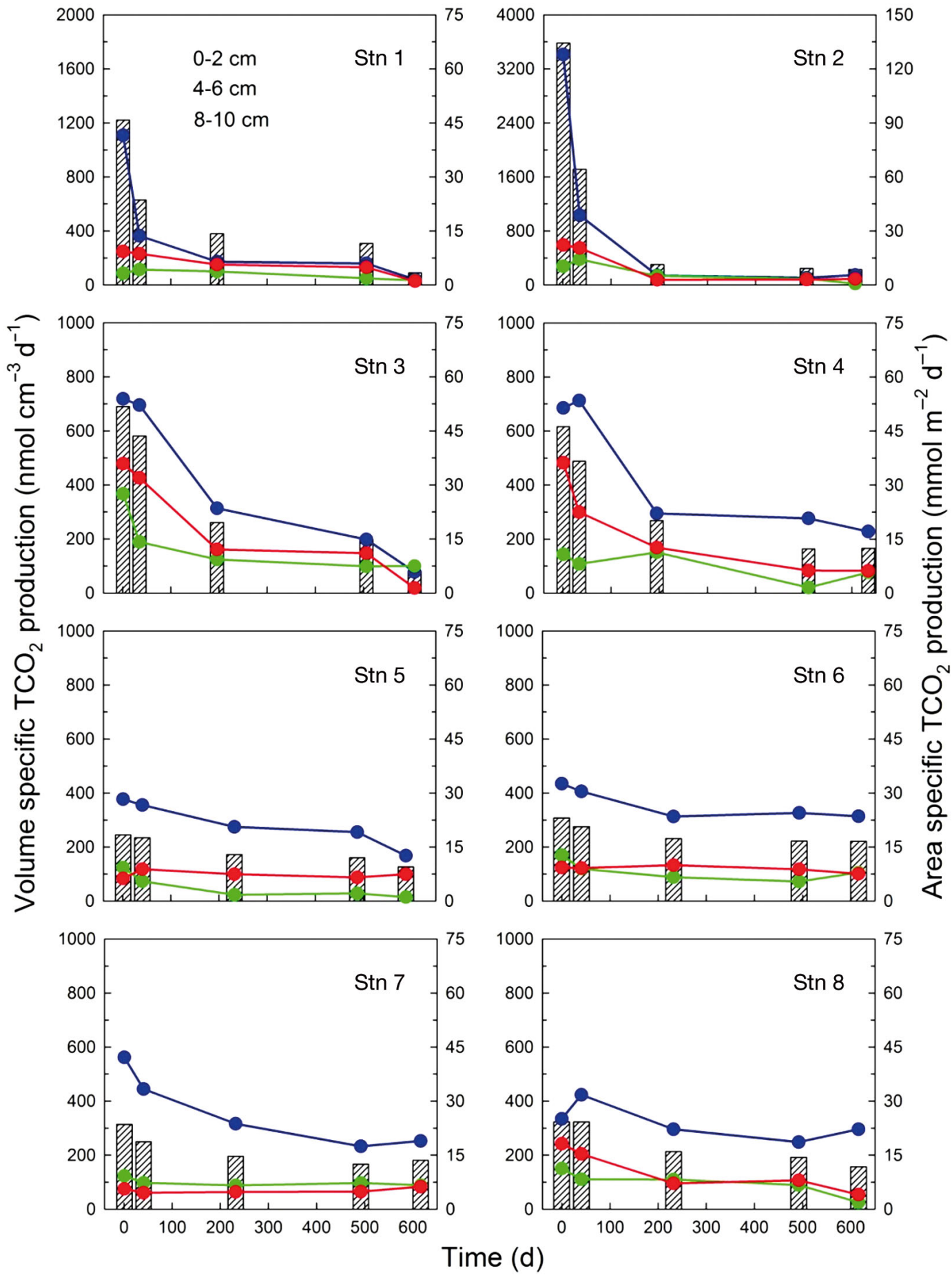

Fig. 5. Volume specific total carbon dioxide $\left(\mathrm{TCO}_{2}\right)$ production rates (left $y$-axis) at different depths over time (blue, red and green line graphs indicate $0-2,4-6$ and $8-10 \mathrm{~cm}$ depth, respectively). Hatched bars indicate total area specific $\mathrm{C}$ mineralization to $10 \mathrm{~cm}$ of depth based on volume specific $\mathrm{TCO}_{2}$-production rates (right $y$-axis). Note the different scaling of the $y$-axes

\section{Exponential decay}

The temporal development of $\mathrm{C}$ degradation in sediment cores could be described with high precision by fitting our data to a double exponential decay model $\left(\mathrm{R}^{2}>\right.$ 0.9; Table 3, Fig. 6), indicating that degradable organic matter in Odense Fjord sediments consisted of 2 pools with different reactivity. Based on $\mathrm{TCO}_{2}$ effluxes, the reactivity for sedimentary organic matter had 2.4 and 6.3 times higher 
average decay constants $k_{L}$ and $k_{R}$, respectively, in the inner (Stns 1-3) than in the outer (Stns 4-8) fjord (Table 3). Decay models based on depth integrated $\mathrm{TCO}_{2}$ production in jar experiments gave similar results (2.5 and 2.8 times higher average $k_{L}$ and $k_{R_{t}}$ respectively), but with slightly more overlap among stations (Table 3).

The constants, $C_{L}$ and $C_{R}$, showed that degradation of labile organic matter accounted for 59 to $85 \%$ of initial $\mathrm{TCO}_{2}$ effluxes and 22 to $92 \%$ of initial $\mathrm{TCO}_{2}$ production in jar experiments (Table 3). However, the time integrated pool of $O C_{L}$ only accounted for 0.3 to $4.3 \%$ of total OC at the examined stations (Fig. 7), and, when combined with short half lives of 0.04 to $0.22 \mathrm{yr}$ (Table 3 ), $>87 \%$ of $O C_{L}$ was depleted within 40 to $240 \mathrm{~d}$ (Table 3 ). The depletion of $O C_{L}$ probably coincided with the observed stabilization of $\mathrm{TCO}_{2}$ effluxes after $\sim 100$ to $150 \mathrm{~d}$ at the various stations (Fig. 3). The pool size of refractory organic matter, $O C_{R}$, at the different stations was quantitatively more important than $O C_{L}$ and corresponded to 4.4 to $95.7 \%$ of total OC at the various stations (Fig. 7). $O C_{R}$ was characterized by several orders of magnitude longer half lives (1-23 yr) than $O C_{L}$ and provided stable background $\mathrm{C}$ mineralization in all sediments, when $O C_{L}$ was depleted. The sediments at all stations contained significant amounts of degradable OC $\left(=O C_{L}+O C_{R}\right)$ ranging from $5.4-13.5 \%$ (Stns 1-4 and 8) to $57-59 \%$ (Stns $6 \&$ 7) and $100 \%$ (Stn 5) of total OC (Fig. 7). The sediments (exempting Stn 5) therefore contained a large fraction of OC which was non-reactive towards microbial degradation on the time scale examined in this study.

Table 2. Organic C (OC) mineralization over $\sim 600 \mathrm{~d}$ in sediments from Odense Fjord. Initial TOC: content in the upper $20 \mathrm{~cm}$ at the beginning of the experiment. Total OC mineralization was determined as the sum of time integrated total carbon dioxide

$\left(\mathrm{TCO}_{2}\right)$ efflux and $\mathrm{TCO}_{2}$ and dissolved organic carbon (DOC) accumulation in porewater (pw) over the whole experiment

\begin{tabular}{|c|c|c|c|c|c|c|c|c|}
\hline & Stn 1 & Stn 2 & Stn 3 & Stn 4 & Stn 5 & Stn 6 & $\operatorname{Stn} 7$ & Stn 8 \\
\hline Duration of experiment (d) & 607 & 607 & 606 & 634 & 588 & 616 & 616 & 616 \\
\hline Initial TOC $\left(\mathrm{mol} \mathrm{m}^{-2}\right)$ & 180 & 313 & 246 & 230 & 22 & 220 & 257 & 282 \\
\hline $\mathrm{TCO}_{2}$ efflux $\left(\mathrm{mol} \mathrm{m}^{-2}\right)$ & 8.5 & 11.5 & 10.0 & 8.7 & 7.4 & 9.4 & 10.2 & 8.1 \\
\hline $\mathrm{TCO}_{2}$ accumulation, $\mathrm{pw}\left(\mathrm{mol} \mathrm{m}{ }^{-2}\right)$ & 0.8 & 0.5 & 0.7 & 0.8 & 0.8 & 0.9 & 0.9 & 0.9 \\
\hline DOC accumulation, pw ( $\left.\mathrm{mol} \mathrm{m}^{-2}\right)$ & 0.2 & 0.1 & 0.1 & 0.1 & 0.1 & 0.1 & 0.1 & 0.1 \\
\hline Total mineralization $\left(\mathrm{mol} \mathrm{m}^{-2}\right)$ & 9.5 & 12.1 & 10.8 & 9.5 & 8.4 & 10.4 & 11.2 & 9.1 \\
\hline Total mineralization (\% of initial) & 5.3 & 3.9 & 4.4 & 4.1 & 37.7 & 4.7 & 4.4 & 3.2 \\
\hline
\end{tabular}

Table 3. Best fit statistics for total organic C (OC) mineralization (based on either effluxes or jar experiments) fitted to a double exponential decay model in the form $y=C_{L} \times \exp \left(-k_{L} \times x\right)+C_{R} \times \exp \left(-k_{R} \times x\right) . C_{L}$ and $C_{R}$ denote constants and $k_{L}$ and $k_{R}$ denotes first order decay constants $\left(\mathrm{d}^{-1}\right)$ for labile and refractory organic matter, respectively. $\mathrm{T}_{1 / 2}, O C_{L}$ and $\mathrm{T}_{1 / 2}, O C_{R}$ denote the calculated half lives (yr) for labile and refractory OC, respectively

\begin{tabular}{|c|c|c|c|c|c|c|c|c|}
\hline & & $C_{L}$ & $k_{L}$ & $C_{R}$ & $k_{R}$ & $\mathrm{R}^{2}$ & $\mathrm{~T}_{1 / 2}, O C_{L}$ & $\mathrm{~T}_{1 / 2}, O C_{F}$ \\
\hline \multirow[t]{2}{*}{ Stn 1} & Efflux & 47.3 & $5.2 \times 10^{-2}$ & 21.1 & $1.9 \times 10^{-3}$ & 0.90 & 0.04 & 1.00 \\
\hline & Jar & 24.2 & $5.5 \times 10^{-2}$ & 21.6 & $2.0 \times 10^{-3}$ & 0.98 & 0.03 & 0.95 \\
\hline \multirow[t]{2}{*}{ Stn 2} & Efflux & 83.9 & $2.0 \times 10^{-2}$ & 14.3 & $0.5 \times 10^{-3}$ & 0.94 & 0.09 & 3.79 \\
\hline & Jar & 123.2 & $2.4 \times 10^{-2}$ & 11.1 & $0.4 \times 10^{-3}$ & 1.00 & 0.08 & 4.75 \\
\hline \multirow[t]{2}{*}{ Stn 3} & Efflux & 104.0 & $4.3 \times 10^{-2}$ & 21.4 & $2.0 \times 10^{-3}$ & 0.98 & 0.04 & 0.95 \\
\hline & Jar & 29.4 & $1.0 \times 10^{-2}$ & 23.0 & $1.5 \times 10^{-3}$ & 0.98 & 0.19 & 1.27 \\
\hline \multirow[t]{2}{*}{ Stn 4} & Efflux & 33.4 & $1.4 \times 10^{-2}$ & 11.4 & $0.4 \times 10^{-3}$ & 0.91 & 0.14 & 2.09 \\
\hline & Jar & 25.4 & $1.2 \times 10^{-2}$ & 20.7 & $0.9 \times 10^{-3}$ & 1.00 & 0.16 & 2.11 \\
\hline \multirow[t]{2}{*}{ Stn 5} & Efflux & 19.8 & $2.1 \times 10^{-2}$ & 11.7 & $0.2 \times 10^{-3}$ & 0.92 & 0.09 & 9.50 \\
\hline & Jar & 3.4 & $0.9 \times 10^{-2}$ & 15.2 & $0.7 \times 10^{-3}$ & 0.96 & 0.21 & 2.71 \\
\hline \multirow[t]{2}{*}{ Stn 6} & Efflux & 26.4 & $1.2 \times 10^{-2}$ & 12.3 & $0.1 \times 10^{-3}$ & 0.95 & 0.16 & 19.0 \\
\hline & Jar & 5.8 & $1.3 \times 10^{-2}$ & 17.3 & $0.1 \times 10^{-3}$ & 1.00 & 0.15 & 19.0 \\
\hline \multirow[t]{2}{*}{ Stn 7} & Efflux & 25.7 & $0.9 \times 10^{-2}$ & 12.1 & $0.1 \times 10^{-3}$ & 0.93 & 0.21 & 19.0 \\
\hline & Jar & 8.4 & $2.0 \times 10^{-2}$ & 15.2 & $0.3 \times 10^{-3}$ & 0.99 & 0.09 & 6.33 \\
\hline \multirow[t]{2}{*}{ Stn 8} & Efflux & 20.1 & $2.6 \times 10^{-2}$ & 13.7 & $0.4 \times 10^{-3}$ & 0.94 & 0.07 & 4.75 \\
\hline & Jar & 10.6 & $0.5 \times 10^{-2}$ & 14.4 & $0.3 \times 10^{-3}$ & 0.97 & 0.38 & 6.33 \\
\hline
\end{tabular}



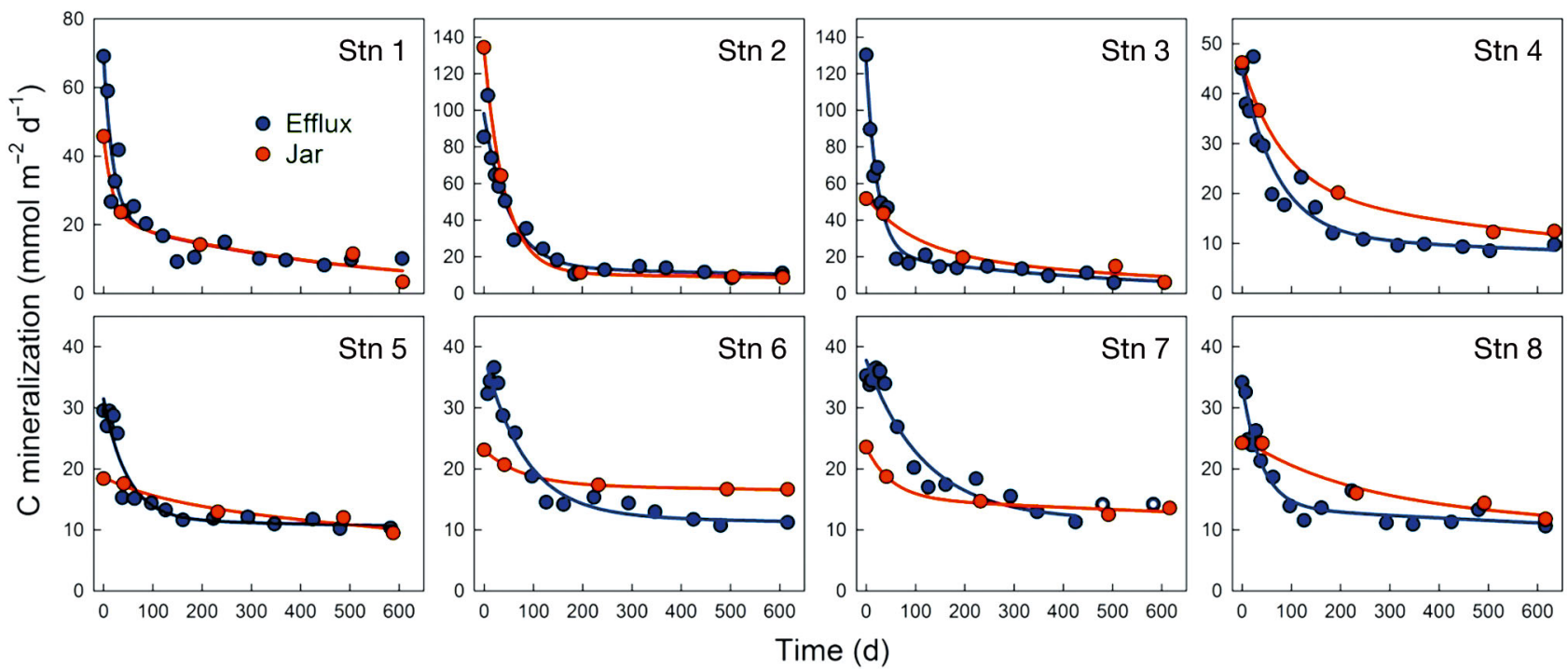

Fig. 6. C mineralization based on total organic carbon $\left(\mathrm{TCO}_{2}\right)$ effluxes and depth integrated $\mathrm{TCO}_{2}$ production in jar experiments (blue and red symbols, respectively) fitted to double exponential regression models (blue and red lines, respectively).

Open symbols were omitted from regressions (only 2 data points for Stn 7). Note the different scaling of the $y$-axes

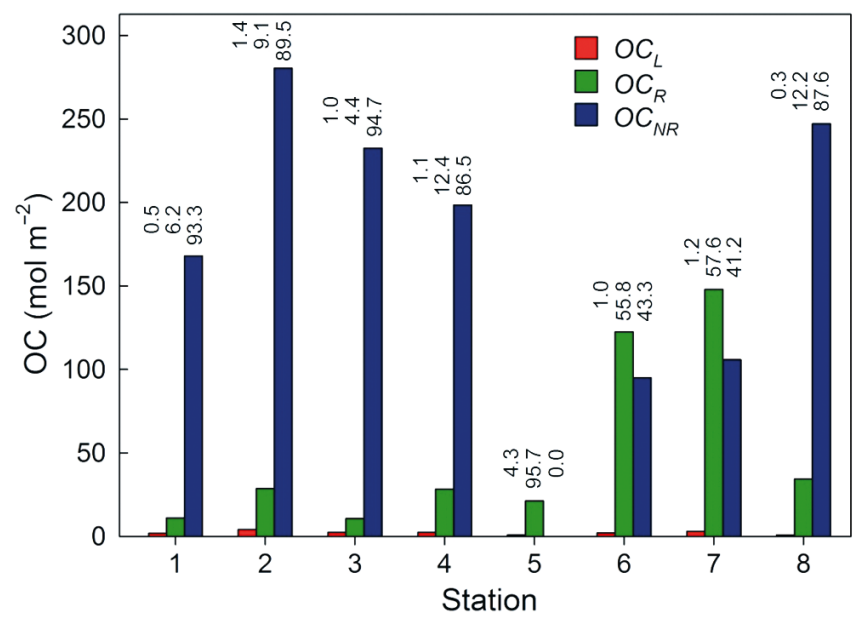

Fig. 7. Organic C (OC) in the upper $20 \mathrm{~cm}$ of sediment. $O C_{L}$ (red bars), $O C_{R}$ (green bars) and $O C_{N R}$ (blue bars) indicate labile, refractory and non-reactive $\mathrm{OC}$, respectively. Numbers above bars indicate the relative contribution (\%)

\section{DISCUSSION}

\section{Initial levels of organic carbon}

Estuaries are frequently nutrient rich and productive and can have high background levels of sediment organic matter compared to open coastal environments. Nonetheless, sediment OC content is typically $<1 \%$ in estuaries with little or no anthropogenic influence (Zimmerman \& Canuel 2002, Zhang et al. 2009). OC content in eutrophic estuaries is frequently higher $(1-10 \%)$, especially in areas close to the river mouths and in deep sedimentation basins (Zimmerman \& Canuel 2002, De Falco et al. 2004). No historical records of sedimentary $\mathrm{OC}$ are available for the stations studied in this experiment, but the initial conditions, with high OC content ( $>1 \%$ ) at most of the stations, are likely a reflection of the eutrophic conditions in Odense Fjord. OC content was either constant (Stn 1) or increased with depth (Stns 2-4 and 7-8) at most of the stations, and only 1 station (Stn 6) showed exponentially decreasing OC with depth, which is typical for accreting sediments with limited physical mixing from fauna and resuspension. The downward increasing profiles at Stns 2-4 and 7-8 indicate a complex OC deposition/degradation history, and may reflect a recent decrease in OC input as a result of reduced nutrient loading and primary production in Odense Fjord as described in Petersen et al. (2009). Only Stn 5 had low organic content $(<0.2 \%)$ due to the wind exposed conditions at this station, where OC content is kept low by frequent sediment resuspension and bioturbation by lugworms (Valdemarsen et al. 2010a, Wendelboe et al. 2013). The initial OC content in the top $20 \mathrm{~cm}$ thus varied $>1$ order of magnitude (from 22 to $313 \mathrm{~mol} \mathrm{~m}^{-2}$ ) and the most organic-rich stations exceeded the threshold of $1 \%$ OC at which sediment stability is diminished.

\section{Microbial degradation pathways}

OC degradation in sediments is driven by a consortium of microbial communities. Particulate OC is first 
split into dissolved organic moieties through extracellular enzymatic attack and subsequent fermentation and hydrolysis, and these are then oxidized to $\mathrm{TCO}_{2}$ by, for example, sulfate reducing bacteria (Canfield et al. 1993, Kristensen \& Holmer 2001, Brüchert \& Arnosti 2003, Valdemarsen \& Kristensen 2010). The results indicate that substantial amounts of $\mathrm{OC}$ were degraded by microbial communities over the $\sim 2$ yr experiment (Table 2). Most of the degraded OC ( 99\%) was oxidized completely to $\mathrm{TCO}_{2}$, which effluxed to the overlying water or accumulated in sediment porewater, whereas only a minor fraction $(\sim 1 \%)$ accumulated as DOC in porewater. DOC fluxes were not measured in this study, since they are usually negligible when compared to $\mathrm{TCO}_{2}$ effluxes and total $\mathrm{C}$ budgets in laboratory experiments with starved sediment cores (e.g. Valdemarsen et al. 2009). Assuming negligible DOC efflux, the modest DOC accumulation in porewater, thus, indicates that initial cleavage and dissolution of particulate OC is intimately linked to DOC oxidation by respiring microbes. This supports the notion that the initial cleavage of particulate organic macromolecules is the rate limiting step for degradation of organic matter in sediments (see review by Arnosti 2011). Nevertheless, the gradual accumulation of porewater DOC observed for all stations indicates that a small but constant proportion of DOC generated by hydrolytic attack and fermentation $(\sim 1 \%)$ is not available for rapid microbial respiration. The composition of accumulated DOC was not analyzed, but it may consist of various compounds (e.g. long chain fatty acids and bacterially derived DOC), which are resistant towards microbial decay in anoxic sediments (Haddad et al. 1992, Harvey et al. 1995, Ogawa et al. 2001, Sun et al. 2002).

We are fairly confident that sulfate reduction was the dominating pathway for terminal OC respiration throughout most of the experiment. In jar experiments, sulfate reduction was clearly the dominating respiration pathway as indicated by the 1:2 stoichiometry between sulfate consumption and $\mathrm{TCO}_{2}$ production. This may, however, be an experimental artifact since other metabolic pathways (e.g. aerobic respiration and metal oxide reduction) are suppressed in closed sediment incubations (Hansen et al. 2000). Degradation of oxygen sensitive OC near the surface in sediment cores may, therefore, explain why OC degradation based $\mathrm{TCO}_{2}$ production from jar experiments was 16 to $60 \%$ lower than that estimated from $\mathrm{TCO}_{2}$ effluxes at the beginning of the experiment. The closer correspondence between these 2 measures after $34 \mathrm{~d}$, however, indicates that sulfate reduc- tion was the dominant pathway in cores during most of the experiment. In any case, the presence of $\mathrm{O}_{2}$ at the sediment-water interface of cores did not, after $1 \mathrm{mo}$, lead to excess $\mathrm{C}$ mineralization.

\section{Organic carbon lability}

The large initial variation in OC degradation among stations, as indicated by the higher $\mathrm{TCO}_{2}$ effluxes in inner compared outer fjord sediments, were mainly due to different $\mathrm{TCO}_{2}$ production in the $0-2 \mathrm{~cm}$ surface sediment. $\mathrm{TCO}_{2}$ production at $4-6$ and $8-10 \mathrm{~cm}$ depth was, on average, also slightly elevated in inner compared to outer fjord sediments, but rates were lower than at the surface and there was marked overlap among stations (Fig. 5). Since all sediments were incubated under similar conditions and between-station variability caused by, for instance, bioturbation (Kristensen et al. 2012) was experimentally removed, the different $\mathrm{OC}$ degradation between stations indicated a gradient of decreasing OC lability from the inner to the outer Odense Fjord.

The apparent differences in OC lability among stations are probably caused by the nutrient concentration gradient in Odense Fjord. Inner fjord stations, especially Stns $1 \& 2$, are strongly affected by nutrient discharge from the Odense River, which results in 5 times higher dissolved $\mathrm{N}$ and $\mathrm{P}$ concentrations in the inner than the outer fjord basin (annual means of dissolved $\mathrm{N}$ and $\mathrm{P}$ ca. 115 and $4 \mu \mathrm{M}$ in the inner fjord; Fyns Amt 2006). The stations in the inner fjord are, therefore, affected by higher local primary production and labile OC deposition to the sediments. Nutrient availability and hence OC deposition is lower in the outer fjord due to dilution with nutrient poor oceanic water from the Kattegat. Furthermore, the relatively deep outer fjord stations also receive large amounts of low quality OC in the form of suspended sediment particles transported from the shallow areas of Odense Fjord (Canal-Verges et al. 2010).

OC degradation followed an exponentially decreasing trend at all stations reflecting a gradual depletion of OC with successively lower reactivity (Westrich \& Berner 1984). The close fit between area specific OC degradation and double exponential decay models observed for all stations, therefore, suggests that reactive components of sedimentary OC degrade as 2 pools with different reactivity. The rate constants (Table 3) showed that the most labile OC pool typically has an order of magnitude higher reactivity than the less reactive pool $\left(k_{L}\right.$ 's ranged between $0.5 \times 10^{-2}$ and $5.5 \times 10^{-2} \mathrm{~d}^{-1}$ and 
$k_{R}$ 's ranged between $0.1 \times 10^{-3}$ and $2.1 \times 10^{-3} \mathrm{~d}^{-1}$ ). These trends and values agree well with the range reported from other coastal sediments (Westrich \& Berner 1984, Burdige 1991, Roden \& Tuttle 1996). Furthermore, the average 2.3 and 6.1 times higher reactivity for labile and refractory $\mathrm{OC}$, respectively, in the inner vs. outer fjord support the predictions based on sediment characteristics.

The large initial differences between OC degradation on the different stations were mainly driven by differences in labile OC near the surface sediment. The jar experiments revealed that the largest temporal attenuation of $\mathrm{TCO}_{2}$ production occurred in nearsurface sediment, where the concentration of labile OC is typically highest. The exponential decay models based on $\mathrm{TCO}_{2}$ effluxes suggest that labile OC in inner fjord sediments initially accounted for 69 to $85 \%$ of total OC degradation corresponding to 47-104 mmol OC $\mathrm{m}^{-2} \mathrm{~d}^{-1}$. Although labile OC accounted for a similar proportion of initial OC degradation (59-74\%) in outer fjord sediments, the lower total amount and reactivity resulted in a contribution

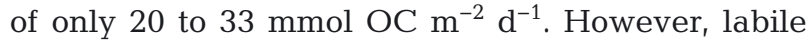
OC has high turnover and the obtained half lives for OC (Table 3) suggested that $>95 \%$ of the labile pool was depleted within 0.5 to $1 \mathrm{yr}$ in inner and outer fjord sediments. The sediment microbial communities must then depend entirely on less labile OC, which constitutes the majority of degradable OC $(82-98 \%)$. The depletion of labile OC may, thus, explain the observed stabilization of $\mathrm{TCO}_{2}$ effluxes to $6-15 \mathrm{mmol} \mathrm{m}^{-2} \mathrm{~d}^{-1}$ on all stations after 100 to $150 \mathrm{~d}$. These observations have wide implications for sediment recovery after organic enrichment. Firstly, initial OC degradation activity may differ widely between locations within an ecosystem, driven by different content and reactivity of labile OC. Secondly, once the labile OC is depleted, degradation of less reactive OC may proceed at similar rates irrespective of location, sediment characteristics, OC content and OC-deposition history.

\section{Non-reactive organic matter}

The difference between total OC measured by chemical analysis and pools of degradable OC calculated based on exponential decay models showed that all stations except Stn 5 had high content (41-95\%; Fig. 7) of non-reactive OC over the time scales studied here (years). Similar results were found in other diagenetically active coastal sediments, where 2 to $86 \%$ of sedimentary OC was found to be non-reactive (Martens \& Klump 1984, Burdige 1991, Roden \& Tuttle 1996). The composition of nonreactive OC is uncertain, but it may originate from various sources (as reviewed in Wakeham \& Canuel 2006, Burdige 2007). For example, in areas impacted by runoff from land, a significant proportion of sediment OC may consist of highly refractory terrestrial OC containing structural components (e.g. lignin; Burdige 2007). Part of sedimentary OC may also become non-reactive towards degradation after protective adsorption to mineral grain surfaces (Hedges \& Keil 1995, Mayer 1999, Pelletier et al. 2011). Nonetheless, the clear relationship between eutrophication and $\mathrm{OC}$ accumulation in sediments (e.g. Zimmerman \& Canuel 2002) suggests that part of the non-reactive $\mathrm{OC}$ in sediments must be derived from more labile organic sources. Phytoplankton and macroalgae debris, which are major sources of OC in eutrophic ecosystems, is generally considered labile towards microbial degradation (Harvey et al. 1995, Flindt et al. 1999, Kristensen \& Holmer 2001). Long term degradation experiments ( $>150 \mathrm{~d})$ show, however, that they contain small amounts of nondegradable OC (Foree \& McCarty 1970, Harvey et al. 1995). It is, therefore, possible that such nondegradable OC have accumulated in Odense Fjord sediments as a result of decades of eutrophication.

Our results show that the sandy and wind exposed Stn 5 only contained degradable $\mathrm{OC}_{\text {, indicating }}$ low accumulation of non-reactive $\mathrm{OC}$ in sediments affected by physical and biological mixing. This may be coupled with frequent sediment resuspension and reworking infauna, which continuously washes away fine particles and old OC (Wendelboe et al. 2013). The mixing processes may also stimulate refractory OC degradation by inducing redox oscillations deep into the sediment (Aller 1994, Hulthe et al. 1998, Kristensen 2000).

\section{Can sediments in eutrophic ecosystems recover from organic enrichment?}

To illustrate temporal recovery trajectories for Odense Fjord, the sediments were divided into 4 different categories based on location, OC content and sediment characteristics: (1) shallow and silty inner fjord (Stns 1-3), (2) shallow and silty outer fjord (Stn 4), (3) shallow and sandy outer fjord (Stn 5) and, finally, (4) deep and silty outer fjord (Stns 6-8). The average decay constants and pool sizes of OC with different reactivity (Table 3, Fig. 7) was then used to calculate the long term fate of 


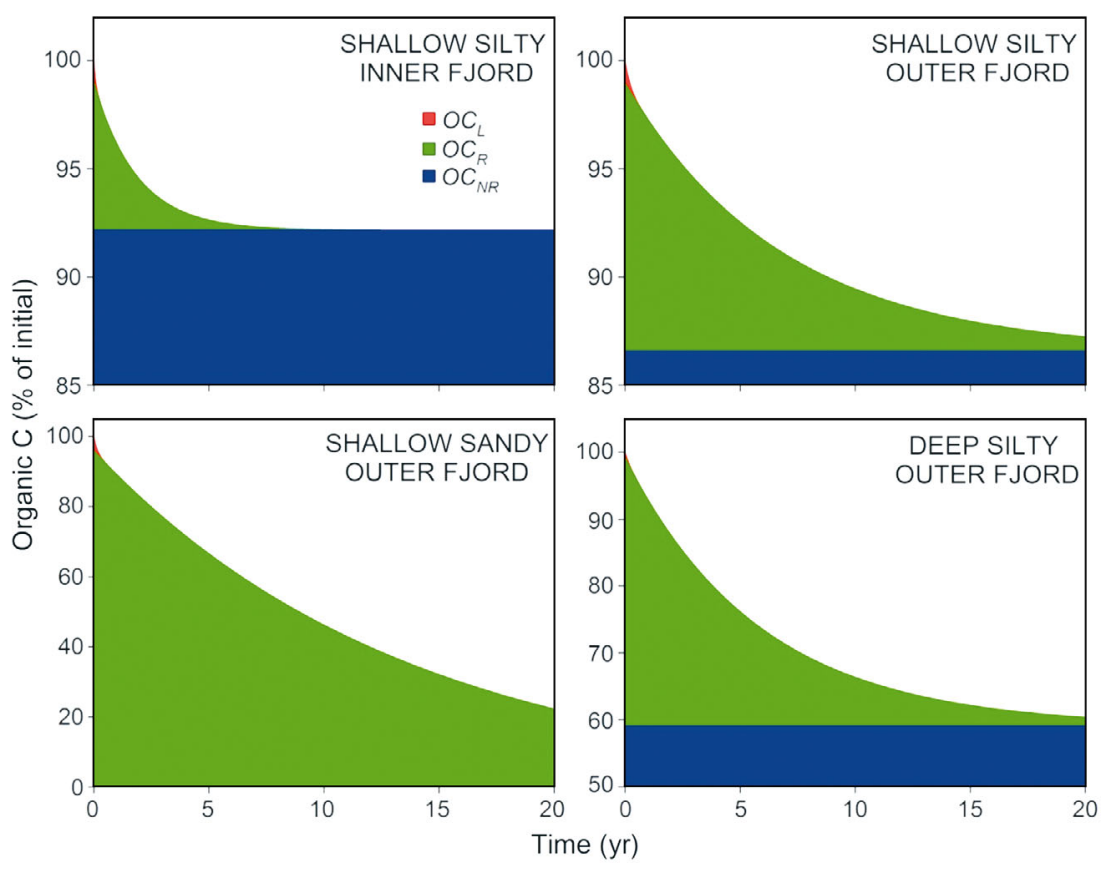

Fig. 8. Extrapolated time dependent degradation of sedimentary organic matter in 4 different habitat types in Odense Fjord. The curvature was calculated based on average pools and reactivities of labile, refractory and non-reactive organic $\mathrm{C}(\mathrm{OC})$ determined by chemical analysis and exponential decay modeling. $O C_{L}$ : labile $\mathrm{C}, O C_{R}$ : refractory $\mathrm{C}, O C_{N R}$ : non-reactive $\mathrm{C}$. Note the different scaling on the $y$-axes

organic matter in these typical habitats of Odense Fjord (Fig. 8). Labile OC, which constitutes only 0.8 to $4 \%$ of total OC in all habitats, is depleted rapidly within 0.5 to $1 \mathrm{yr}$. Likewise, complete degradation of the less reactive OC may cause 7 to $95 \%$ reduction of initial $\mathrm{OC}$ at the various stations within 10 to $50 \mathrm{yr}$ (23 to $50 \mathrm{yr}$ when exempting Stn 5). However, OC can maximally decrease by 8 to $41 \%$ of initial OC in organic-rich and finegrained sediments due to the presence of large amounts of non-reactive OC. Hence, our results indicate that partial recovery of organic enriched sediments in eutrophic ecosystems can occur within decades. However, since a large fraction of sediment organic matter is seemingly non-reactive towards microbial decay, complete natural recovery of organic enriched sediments is impossible. None of the organic-rich sediments included in this study can recover to $<1 \% O C$, and attain optimal surface stability. Eutrophication may, therefore, lead to irreversible accumulation of $\mathrm{OC}$ and associated changes in sediment properties, which may keep ecosystems in a turbid state and prolong ecosystem recovery with respect to, for example, macroalgae and seagrass coverage.

\section{Precautions}

In this study, we measured OC degradation only through microbial processes in defaunated sediment cores and the important effects of macrofauna were ignored. Macrofauna stimulates OC degradation, since burrow ventilation and sediment reworking enhance the exchange of metabolites between sediment and water (e.g. $\mathrm{O}_{2}$ ) and continuously mixes particulate OC between redox zones (Aller 1994, Kristensen 2000, Sun et al. 2002). This promotes the degradation of refractory OC, whereas the turnover of labile OC remains largely unaffected (Hulthe et al. 1998, Kristensen \& Holmer 2001). The exclusion of macrofauna in this study may, therefore, have led to underestimated OC degradation when compared to in situ conditions. In particular, Stns 1-5 are located in areas where large bioturbating polychaetes (e.g. Arenicola marina, Nereis diversicolor and Marenzelleria viridis) capable of stimulating benthic metabolism (Banta et al. 1999, Kristensen 2000, Quintana et al. 2013) are present (Delefosse et al. 2012). However, large species of macrofauna have not been found at the deeper Stns 6-8 (Delefosse et al. 2012). The results from this experiment should, therefore, be extrapolated with caution, since sediment recovery under natural conditions may occur faster in bioturbated sediments.

Addition of fresh organic matter may have a stimulatory effect on the degradation of more refractory organic matter (i.e. priming effect; van Nugteren et al. 2009). Hence, by cutting off the supply of fresh organic matter in this experiment, we may have slowed the degradation of refractory OC. Microbial OC degradation is also strongly dependent on temperature with a typical $Q_{10}$ of 2 to 3 (Westrich \& Berner 1988, Sanz-Lázaro et al. 2011). This experiment was conducted at a constant temperature of $15^{\circ} \mathrm{C}$, which is high compared to the annual temperature conditions in Odense Fjord $\left(2-4^{\circ} \mathrm{C}\right.$ in winter, up to $18^{\circ} \mathrm{C}$ in summer and an annual mean of $8-10^{\circ} \mathrm{C}$ ). Consequently, our experimental conditions may have provided slightly faster OC degradation on an annual basis and overestimated sediment recovery when compared to natural conditions. 


\section{CONCLUSIONS}

We measured the temporal recovery patterns of sediments enriched with organic matter after decades of eutrophication. The results show that OC degradation rates initially differ widely among sediments from different habitats, which is primarily due to different content and reactivity of the most labile OC pools. However, labile OC is rapidly depleted (within 0.5 yr) followed by much slower and more stable microbial degradation rates at a level determined by the content and reactivity of less reactive OC. Our analysis showed that bulk organic matter in enriched sediments from the eutrophic Odense Fjord consists of $0.3-1.4 \%$ and $4-58 \%$ labile and refractory organic matter, respectively. The latter pool is most important for the recovery trajectory of the organicenriched sediments. The results also suggest that complete degradation of reactive organic matter in organic-rich sediments can only be achieved within 23 to 50 yr. Complete recovery of organic-rich sediments to $<1 \%$ OC seems unlikely, however, since the largest fraction of accumulated organic matter (41-95\%) appears non-reactive towards microbial degradation. The sediments in Odense Fjord are, therefore, most likely irreversibly modified by eutrophication, which may have implications for ecosystem recovery during oligotrophication. The situation with organic-enriched sediments and turbid waters observed in many eutrophic estuaries may, therefore, reflect a new steady state imposed by past nutrient enrichment.

Acknowledgements. The authors thank several people who helped with sampling, experimental work or analysis during this experiment (the crew aboard 'Liv II', B. Christensen, R. Orloff Holm, M. Del Mar Sánchez Huertas and M. Jensen). This project was funded by the Danish Strategic Science Foundation through grant 09-063190/DSF.

\section{LITERATURE CITED}

Aller RC (1994) Bioturbation and remineralization of sedimentary organic matter: effects of redox oscillation. Chem Geol 114:331-345

> Aller RC, Yingst JY (1980) Relationships between microbial distributions and the anaerobic decomposition of organic matter in surface sediments of Long Island Sound, USA. Mar Biol 56:29-42

> Amos CL, Bergamasco A, Umgiesser G, Cappucci S and others (2004) The stability of tidal flats in Venice Lagoon-the results of in-situ measurements using 2 benthic, annular flumes. J Mar Syst 51:211-241

Arnosti C (2011) Microbial extracellular enzymes and the marine carbon cycle. Annu Rev Mar Sci 3:401-425
Bale AJ, Kenny AJ (2005) Sediment analysis and seabed characterization. In: Eleftheriou A, McIntyre A (eds) Methods for the study of marine benthos. Blackwell Science, Oxford

> Banta GT, Holmer M, Jensen MH, Kristensen E (1999) Effects of 2 polychaete worms, Nereis diversicolor and Arenicola marina, on aerobic and anaerobic decomposition in a sandy marine sediment. Aquat Microb Ecol 19: 189-204

> Borja A, Dauer DM, Elliott M, Simenstad CA (2010) Medium- and long-term recovery of estuarine and coastal ecosystems: patterns, rates and restoration effectiveness. Estuaries Coasts 33:1249-1260

Brüchert V, Arnosti C (2003) Anaerobic carbon transformation: experimental studies with flow-through cells. Mar Chem 80:171-183

Burdige DJ (1991) The kinetics of organic-matter mineralization in anoxic marine sediments. J Mar Res 49: $727-761$

> Burdige DJ (2007) Preservation of organic matter in marine sediments: controls, mechanisms, and an imbalance in sediment organic carbon budgets? Chem Rev 107: 467-485

Canal-Verges P, Vedel M, Valdemarsen T, Kristensen E, Flindt MR (2010) Resuspension created by bedload transport of macroalgae: implications for ecosystem functioning. Hydrobiologia 649:69-76

Canfield DE, Jørgensen BB, Fossing H, Glud R and others (1993) Pathways of organic carbon oxidation in 3 continental margin sediments. Mar Geol 113:27-40

De Falco G, Magni P, Terasvuori LMH, Matteucci G (2004) Sediment grain size and organic carbon distribution in the Cabras Lagoon (Sardinia, Western Mediterranean). Chem Ecol 20 (Suppl 1):367-377

> Delefosse M, Banta GT, Canal-Vergés P, Penha-Lopes G, Quintana C, Valdemarsen T, Kristensen E (2012) Macrobenthic community response to the Marenzelleria viridis (Polychaeta) invasion of a Danish estuary. Mar Ecol Prog Ser 461:83-94

> Duarte CM, Conley DJ, Carstensen J, Sanchez-Camacho M (2009) Return to Neverland: shifting baselines affect eutrophication restoration targets. Estuaries Coasts 32: 29-36

Flindt MR, Pardal MÂ, Lillebø AI, Martins I, Marques JC (1999) Nutrient cycling and plant dynamics in estuaries: a brief review. Acta Oecol 20:237-248

- Foree EG, McCarty PL (1970) Anaerobic decomposition of algae. Environ Sci Technol 4:842-849

Fyns Amt (2006) Miljøfarlige stoffer og Ålegræs i Odense Fjord. Fyns Amt, Natur- og Vandmiljøafdelingen, Odense

- Glud RN (2008) Oxygen dynamics of marine sediments. Mar Biol Res 4:243-289

> Gray JS, Wu RSS, Or YY (2002) Effects of hypoxia and organic enrichment on the coastal marine environment. Mar Ecol Prog Ser 238:249-279

- Greve TM, Krause-Jensen D, Rasmussen MB, Christensen PB (2005) Means of rapid eelgrass (Zostera marina L.) recolonisation in former dieback areas. Aquat Bot 82: 143-156

- Haddad RI, Martens CS, Farrington JW (1992) Quantifying early diagenesis of fatty-acids in a rapidly accumulating coastal marine sediment. Org Geochem 19:205-216

$>$ Hall POJ, Aller RC (1992) Rapid, small-volume, flow injection analysis for $\Sigma \mathrm{CO}_{2}$ and $\mathrm{NH}_{4}{ }^{+}$in marine and freshwaters. Limnol Oceanogr 37:1113-1119 
Hansen JW, Thamdrup B, Jørgensen BB (2000) Anoxic incubation of sediment in gas-tight plastic bags: a method for biogeochemical process studies. Mar Ecol Prog Ser 208: 273-282

> Harvey HR, Tuttle JH, Bell JT (1995) Kinetics of phytoplankton decay during simulated sedimentation - changes in biochemical composition and microbial activity under oxic and anoxic conditions. Geochim Cosmochim Acta 59:3367-3377

> Hedges JI, Keil RG (1995) Sedimentary organic matter preservation: an assessment and speculative synthesis. Mar Chem 49:81-115

> Hulthe G, Hulth S, Hall POJ (1998) Effect of oxygen on degradation rate of refractory and labile organic matter in continental margin sediments. Geochim Cosmochim Acta 62:1319-1328

> Jones HP, Schmitz OJ (2009) Rapid recovery of damaged ecosystems. PLoS ONE 4: e5653

Kemp WM, Testa JM, Conley DJ, Gilbert D, Hagy JD (2009) Temporal responses of coastal hypoxia to nutrient loading and physical controls. Biogeosciences 6:2985-3008

Kristensen E (2000) Organic matter diagenesis at the oxic/ anoxic interface in coastal marine sediments, with emphasis on the role of burrowing animals. Hydrobiologia 426:1-24

Kristensen E, Andersen FO (1987) Determination of organiccarbon in marine-sediments - a comparison of $2 \mathrm{CHN}$ analyzer methods. J Exp Mar Biol Ecol 109:15-23

Kristensen E, Hansen K (1995) Decay of plant detritus in organic-poor marine sediment: production rates and stoichiometry of dissolved $\mathrm{C}$ and $\mathrm{N}$ compounds. J Mar Res 53:675-702

Kristensen E, Holmer M (2001) Decomposition of plant materials in marine sediment exposed to different electron acceptors $\left(\mathrm{O}_{2}, \mathrm{NO}_{3}{ }^{-}\right.$, and $\left.\mathrm{SO}_{4}{ }^{2-}\right)$, with emphasis on substrate origin, degradation kinetics, and the role of sulfate reduction. Geochim Cosmochim Acta 65:419-433

Kristensen E, Ahmed SI, Devol AH (1995) Aerobic and anaerobic decomposition of organic matter in marine sediment: which is fastest? Limnol Oceanogr 40:1430-1437

- Kristensen E, Penha-Lopes G, Delefosse M, Valdemarsen T, Quintana C, Banta GT (2012) What is bioturbation? The need for a precise definition for fauna in aquatic sciences. Mar Ecol Prog Ser 446:285-302

Kronvang B, Jeppesen E, Conley DJ, Sondergaard M, Larsen SE, Ovesen NB, Carstensen J (2005) Nutrient pressures and ecological responses to nutrient loading reductions in Danish streams, lakes and coastal waters. J Hydrol 304:274-288

Lehmann MF, Bernasconi SM, Barbieri A, McKenzie JA (2002) Preservation of organic matter and alteration of its carbon and nitrogen isotope composition during simulated and in situ early sedimentary diagenesis. Geochim Cosmochim Acta 66:3573-3584

Lillebø AI, Flindt MR, Cardoso PG, Leston S and others (2012) Restoration of seagrass community to reverse eutrophication in estuaries. In: Chicharo L, Zalewski M (eds) Treatise on estuarine and coastal science. Academic Press, Waltham

Lundkvist M (2008) The influence of benthic organisms on cohesive sediment characteristics, erodability and consolidation. PhD thesis, University of Southern Denmark, Odense $M$

Lundkvist M, Grue M, Friend P, Flindt MR (2007) The relative contributions of physical and microbiological factors to cohesive sediment stability. Cont Shelf Res $27: 1143-1152$

> Martens CS, Klump J (1984) Biogeochemical cycling in an organic-rich coastal marine basin 4. An organic carbon budget for sediments dominated by sulfate reduction and methanogenesis. Geochim Cosmochim Acta 48: 1987-2004

- Mascaro O, Valdemarsen T, Holmer M, Perez M, Romero J (2009) Experimental manipulation of sediment organic content and water column aeration reduces Zostera marina (eelgrass) growth and survival. J Exp Mar Biol Ecol 373:26-34

Mayer LM (1999) Extent of coverage of mineral surfaces by organic matter in marine sediments. Geochim Cosmochim Acta 63:207-215

Nixon SW (1995) Coastal marine eutrophication-a definition, social causes, and future concerns. Ophelia 41: 199-219

Nixon SW (2009) Eutrophication and the macroscope. Hydrobiologia 629:5-19

- Ogawa H, Amagai Y, Koike I, Kaiser K, Benner R (2001) Production of refractory dissolved organic matter by bacteria. Science 292:917-920

Orth RJ, Carruthers TJB, Dennison WC, Duarte CM and others (2006) A global crisis for seagrass ecosystems. Bioscience 56:987-996

> Pallud C, Van Cappellen P (2006) Kinetics of microbial sulfate reduction in estuarine sediments. Geochim Cosmochim Acta 70:1148-1162

Pelletier MC, Campbell DE, Ho KT, Burgess RM, Audette CT, Detenbeck NE (2011) Can sediment total organic carbon and grain size be used to diagnose organic enrichment in estuaries? Environ Toxicol Chem 30:538-547

Petersen JD, Rask N, Madsen HB, Jorgensen OT and others (2009) Odense Pilot River Basin: implementation of the EU Water Framework Directive in a shallow eutrophic estuary (Odense Fjord, Denmark) and its upstream catchment. Hydrobiologia 629:71-89

Quintana CO, Kristensen E, Valdemarsen T (2013) Impact of the invasive polychaete Marenzelleria viridis on the biogeochemistry of sandy marine sediments. Biogeochemistry 115:95-109

$>$ Roden EE, Tuttle JH (1996) Carbon cycling in mesohaline Chesapeake Bay sediments. 2. Kinetics of particulate and dissolved organic carbon turnover. J Mar Res 54: 343-383

Sanz-Lázaro C, Valdemarsen T, Marin A, Holmer M (2011) Effect of temperature on biogeochemistry of marine organic-enriched systems: implications in a global warming scenario. Ecol Appl 21:2664-2677

Sun MY, Aller RC, Lee C, Wakeham SG (2002) Effects of oxygen and redox oscillation on degradation of cellassociated lipids in surficial marine sediments. Geochim Cosmochim Acta 66:2003-2012

> Vaalgamaa S (2004) The effect of urbanisation on Laajalahti Bay, Helsinki City, as reflected by sediment geochemistry. Mar Pollut Bull 48:650-662

> Valdemarsen T, Kristensen E (2005) Diffusion scale dependent change in anaerobic carbon and nitrogen mineralization: true effect or experimental artifact? J Mar Res 63: 645-669

Valdemarsen T, Kristensen E (2010) Degradation of dissolved organic monomers and short-chain fatty acids in sandy marine sediment by fermentation and sulfate reduction. Geochim Cosmochim Acta 74:1593-1605 
Valdemarsen T, Kristensen E, Holmer M (2009) Metabolic threshold and sulfide-buffering in diffusion controlled marine sediments impacted by continuous organic enrichment. Biogeochemistry 95:335-353

Valdemarsen T, Kristensen E, Holmer M (2010a) Sulfur, carbon, and nitrogen cycling in faunated marine sediments impacted by repeated organic enrichment. Mar Ecol Prog Ser 400:37-53

Valdemarsen T, Canal-Vergés P, Kristensen E, Holmer M, Kristiansen MD, Flindt MR (2010b) Vulnerability of Zostera marina seedlings to physical stress. Mar Ecol Prog Ser 418:119-130

Valdemarsen T, Bannister RJ, Hansen PK, Holmer M, Ervik A (2012) Biogeochemical malfunctioning in sediments beneath a deep-water fish farm. Environ Pollut 170: $15-25$

van Nugteren P, Moodley L, Brummer GJ, Heip CHR, Herman PMJ, Middelburg JJ (2009) Seafloor ecosystem functioning: the importance of organic matter priming. Mar Biol 156:2277-2287

Wakeham S, Canuel E (2006) Degradation and preservation of organic matter in marine sediments. In: Volkman J (ed) Marine organic matter: biomarkers, isotopes and DNA, Book 2N. Springer, Berlin Heidelberg

Wendelboe K, Egelund JT, Flindt MR, Valdemarsen T (2013)

Editorial responsibility: Ronald Kiene,

Mobile, Alabama, USA
Impact of lugworms (Arenicola marina) on mobilization and transport of fine particles and organic matter in marine sediments. J Sea Res 76:31-38

- Westrich JT, Berner RA (1984) The role of sedimentary organic matter in bacterial sulfate reduction: the G-model tested. Limnol Oceanogr 29:236-249

Westrich JT, Berner RA (1988) The effect of temperature on rates of sulfate reduction in marine sediments. Geomicrobiol J 6:99-117

Wetz MS, Hales B, Wheeler PA (2008) Degradation of phytoplankton-derived organic matter: implications for carbon and nitrogen biogeochemistry in coastal ecosystems. Estuar Coast Shelf Sci 77:422-432

Wicks EC, Koch EW, O'Neil JM, Elliston K (2009) Effects of sediment organic content and hydrodynamic conditions on the growth and distribution of Zostera marina. Mar Ecol Prog Ser 378:71-80

Zhang L, Yin KD, Wang L, Chen FR, Zhang DR, Yang YQ (2009) The sources and accumulation rate of sedimentary organic matter in the Pearl River Estuary and adjacent coastal area, Southern China. Estuar Coast Shelf Sci 85: 190-196

Zimmerman AR, Canuel EA (2002) Sediment geochemical records of eutrophication in the mesohaline Chesapeake Bay. Limnol Oceanogr 47:1084-1093

Submitted: August 5, 2013; Accepted: January 29, 2014 Proofs received from author(s): March 25, 2014 